\title{
Paleoelevation estimates for the northern and central proto- Basin and Range from carbonate clumped isotope thermometry
}

\author{
Alex R. Lechler, ${ }^{1,2}$ Nathan A. Niemi, ${ }^{1}$ Michael T. Hren, ${ }^{1,3}$ and Kyger C. Lohmann ${ }^{1}$ \\ Received 19 September 2012; revised 4 January 2013; accepted 30 January 2013; published 30 May 2013.
}

[1] Quantitative paleoelevation histories can help explain both why and how widespread Cenozoic extension occurred in the Basin and Range Province of western North America. We present new estimates of preextensional paleoelevations for the northern and central Basin and Range using clumped isotope $\left(\Delta_{47}\right)$ thermometry of lacustrine carbonates collected from each region. Comparison of carbonate $\Delta_{47}$-derived mean annual air temperature (MAAT) estimates $\left(\sim 16^{\circ} \mathrm{C}-20^{\circ} \mathrm{C}\right)$ for the Late Cretaceous-Eocene Sheep Pass basin of east central Nevada with published MAAT estimates for the Eocene, coastal northern Sierra Nevada $\left(20^{\circ} \mathrm{C}-25^{\circ} \mathrm{C}\right)$, suggests that the early Paleogene Sheep Pass basin had a paleoelevation of $\leq 2 \mathrm{~km}$. Such a modest paleoelevation suggests that either (1) the proto-northern Basin and Range did not attain maximum paleoelevations of 3-4 km until the late Eocene-early Oligocene; or (2) the Sheep Pass basin was a local, high-relief $(>1 \mathrm{~km}$ ) setting contained within a $>3 \mathrm{~km}$ orogenic highland ("Nevadaplano"). Similarity of $\Delta_{47}$-derived MAAT estimates $\left(\sim 17^{\circ} \mathrm{C}-24^{\circ} \mathrm{C}\right)$ for carbonates from the central Basin and Range and the near-sea level southern Sierra Nevada Bena basin indicate that middle Miocene paleoelevations in the Death Valley region were $\leq 1.5 \mathrm{~km}$. These fairly low paleoelevations are incompatible with preextensional crustal thicknesses $>52 \mathrm{~km}$ and indicate that mean elevation change was minor $(\leq 500 \mathrm{~m})$ and lithospheric mass was not conserved during $>100 \%$ Neogene extension of the central Basin and Range, but was instead likely compensated by synextensional magmatic additions to the crust.

Citation: Lechler, A. R., N. A. Niemi, M. T. Hren, and K. C. Lohmann (2013), Paleoelevation estimates for the northern and central proto-Basin and Range from carbonate clumped isotope thermometry, Tectonics, 32, 295-316, doi:10.1002/tect.20016.

\section{Introduction}

[2] Accurate quantitative paleoelevation histories are critical to the development and validation of tectonic and geodynamic models of orogen evolution. In the case of the North American Cordillera, constraining the Cenozoic paleoelevation history of the western U.S. Cordilleran interior (i.e., proto-Basin and Range) is essential to identifying the primary driving forces for Cenozoic extension as well as constraining the mechanisms by which this extension has been accommodated [e.g., Sonder and Jones, 1999]. Unfortunately, robust measures of absolute paleoelevations in the preextensional Basin and Range Province are scarce, particularly south of $37^{\circ} \mathrm{N}$, where $>100 \%$ extension since the middle Miocene has more than doubled the width of the central Basin and Range (CBR) [Stewart, 1983; Wernicke et al., 1988; Snow and Wernicke,

\footnotetext{
${ }^{1}$ Department of Earth and Environmental Sciences, University of Michigan, Ann Arbor, Michigan, USA.

${ }^{2}$ Department of Earth and Planetary Sciences, Northrop Hall, University of New Mexico, Albuquerque, New Mexico, USA.

${ }^{3}$ Center for Integrative Geosciences, University of Connecticut, Storrs, Connecticut, USA.

Corresponding author: A. R. Lechler, Department of Earth and Planetary Sciences, Northrop Hall, MSC03-2040, University of New Mexico, Albuquerque, NM 87131, USA. (lechler@unm.edu)

(C)2013. American Geophysical Union. All Rights Reserved. 0278-7404/13/10.1002/tect.20016
}

2000; Niemi et al., 2001; McQuarrie and Wernicke, 2005; Niemi, 2013; Renik and Christie-Blick, 2013]. Despite large-magnitude extension, modern crustal thicknesses throughout the central Basin and Range remain moderate (30-34 km) [Schulte-Pelkum et al., 2011], suggesting that either preextensional crustal thickness was very high (>50 km) [Coney and Harms, 1984; Best et al., 2009; Ernst, 2010] or that crustal material has been added during extension, either by flow in from surrounding areas (e.g., the Sierra Nevada) [Wernicke et al., 1996] or by magmatic addition within or at the base of the crust [e.g., Lachenbruch and Morgan, 1990; Hawkesworth et al., 1995]. Isostatic compensation of thick, preextensional crust would have resulted in high $(>3 \mathrm{~km})$ pre-middle Miocene paleoelevations in the $\mathrm{CBR}$, but direct evidence for such high paleotopography is currently lacking.

[3] In contrast to the central Basin and Range, the adjacent northern Basin and Range (NBR) has a comparatively wellestablished preextensional elevation history despite limited absolute paleoelevation constraints [e.g., Ernst, 2010; Henry et al., 2012; Chamberlain et al., 2012]. The few absolute measures of regional paleoelevations are derived from paleobotanical (i.e., leaf physiognomy) methods that consistently suggest that middle Eocene-Oligocene paleoelevations in the NBR were 2-4 km [Gregory-Wodzicki, 1997; Chase et al., 1998; Wolfe et al., 1998], though there is ongoing debate over the validity of some paleobotanical measures of 
paleoelevation [Peppe et al., 2010]. These paleobotanicalbased paleoelevation estimates are in general agreement with paleoelevation interpretations derived from regional Eocene-Oligocene ash flow tuff dispersal patterns [Henry, 2008; Cassel et al., 2009a, 2012; Henry and Faulds, 2010; Henry et al., 2012] and proposed paleoelevations based on preextensional crustal thickness estimates of $>50 \mathrm{~km}$ [Coney and Harms, 1984; Gans, 1987; DeCelles, 2004; DeCelles and Coogan, 2006; Best et al., 2009; Ernst, 2010], all of which suggest that the proto-NBR was characterized by a highelevation $(>3 \mathrm{~km})$ orogenic plateau (termed "Nevadaplano," based on analogy to the Andean Altiplano by DeCelles [2004]) that formed in Late Cretaceous-early Paleogene time during shortening associated with the Sevier orogeny [e.g., Dilek and Moores, 1999; Dickinson, 2006]. In contrast, regional paleometeoric water proxy isotopic $\left(\delta \mathrm{D}\right.$ and $\left.\delta^{18} \mathrm{O}\right)$ data have been interpreted as indicating that this orogenic highland did not attain $3-4 \mathrm{~km}$ paleoelevations until late Eocene-Oligocene time, following a southward sweep of surface uplift $(\sim 1-3 \mathrm{~km})$ associated with north-to-south removal of the Farallon slab [Horton et al., 2004; Mix et al., 2011; Chamberlain et al., 2012]. If true, these stable isotope paleoaltimetry interpretations suggest that the Nevadaplano was not constructed solely by Sevier contraction and may have been characterized by moderate $(\leq 2 \mathrm{~km})$ paleoelevations prior to the late Eocene.

[4] Proxy stable isotope records have also served as the basis for central Basin and Range paleoelevation interpretations. An observed increase in paleometeoric water proxy $\delta^{18} \mathrm{O}$ values since the middle Miocene has been interpreted as reflecting $\sim 1-3 \mathrm{~km}$ of topographic lowering of the central Basin and Range as a result of Neogene extension [Horton and Chamberlain, 2006; Chamberlain et al., 2012]. Given modern regional mean elevations of $\sim 1 \mathrm{~km}, 1-3 \mathrm{~km}$ of surface elevation decrease would require that pre-middle Miocene paleoelevations in the central Basin and Range were $\sim 2-4 \mathrm{~km}$. Such paleoelevations would have been similar to those proposed for the Nevadaplano and would imply that a high-elevation Paleogene orogenic plateau extended throughout the northern and central Basin and Range [Ernst, 2010].

[5] Deriving paleoelevations from paleometeoric water proxy isotopic records is not straightforward, however. Such records are highly sensitive to changes in climate through time, particularly the sources for and trajectories by which meteoric precipitation was delivered to the site of proxy formation [e.g., Lechler and Galewsky, 2013]. The fact that the observed increase in CBR paleometeoric water proxy $\delta^{18} \mathrm{O}$ values since the middle Miocene coincides with the tectonic opening of the Gulf of California [Oskin et al., 2001] calls into question whether the increase in $\delta^{18} \mathrm{O}$ values is the result of $1-3 \mathrm{~km}$ of surface downdrop or may simply be a reflection of an increased influence of southern, high $\delta^{18} \mathrm{O}$ moisture sources to central Basin and Range precipitation since the middle Miocene [Horton and Chamberlain, 2006; Lechler and Niemi, 2011a]. Such ambiguities leave the preextensional paleoelevation history of the central Basin and Range open to debate.

[6] Assuming that the northern and central Basin and Range share a similar paleoelevation history is particularly problematic given the variability in both timing and magnitude of Cenozoic extension throughout the Basin and Range
[Sonder and Jones, 1999; Snow and Wernicke, 2000; McQuarrie and Wernicke, 2005]. Thus, it is not only permissible but likely that preextensional paleoelevation histories were also variable throughout the Basin and Range. Of particular interest is understanding the degree to which modern topographic heterogeneity, where CBR mean elevations are $\sim 1 \mathrm{~km}$ lower than those in the NBR, is the result of variable Cenozoic extension magnitudes in the CBR (>100\%) [Wernicke et al., 1988; Snow and Wernicke, 2000; McQuarrie and Wernicke, 2005] and NBR ( 40\%-50\%) [e.g., Colgan and Henry, 2009, and references therein], or if modern topography reflects inherited Sevier and Laramide tectonic signatures [e.g., Jones et al., 1992; Schulte-Pelkum et al., 2011].

[7] In this study, we apply clumped isotope thermometry to continental interior and contemporaneous paleo-sea level lacustrine carbonates to provide new measures of preextensional absolute paleoelevations of the northern and central Basin and Range. This study tests the existence, and constrains the geographic extent, of the proposed early to middle Cenozoic Cordilleran interior Nevadaplano and provides a direct measure of the amount of CBR surface elevation change that resulted from Cenozoic extension. Such measures of synextensional elevation change potentially provide information about both extension mechanisms and the degree to which crustal and lithospheric mass has been conserved during largemagnitude Basin and Range extension.

\section{Carbonate Clumped Isotope $\left(\Delta_{47}\right)$ Paleoaltimetry}

[8] Carbonate clumped isotope thermometry utilizes the temperature dependence of ${ }^{13} \mathrm{C}-{ }^{18} \mathrm{O}$ bond abundance (degree of "clumping"; $\Delta_{47}$ value) in the carbonate crystal lattice to constrain temperatures of carbonate formation, independent of carbonate stable isotopic $\left(\delta^{18} \mathrm{O}, \delta^{13} \mathrm{C}\right)$ compositions [e.g., Ghosh et al., 2006a; Huntington et al., 2009; Eiler, 2011]. Obtaining independent measures of temperature of carbonate growth and/or diagenetic resetting is a powerful tool for stable isotope-based paleoclimate, hydrologic, and paleoelevation investigations. For many such studies, and particularly in the case of stable isotope paleoaltimetry, the environmental parameter of interest is the isotopic composition of the meteoric water from which the carbonate proxy precipitated. Quantifying the relationship between water and carbonate isotopic compositions can be complicated, however, due to temperature-dependent fractionation between the two phases [e.g., Kim and O'Neil, 1997]. As a result, uncertainty about the temperature of carbonate formation leads to uncertainty in the calculated water isotopic compositions. With independent measures of carbonate formation temperature, water $\delta^{18} \mathrm{O}$ values can be calculated directly.

[9] Quantification of carbonate formation temperatures can also function as a powerful tool in paleoaltimetry studies, independent of calculated water $\delta^{18} \mathrm{O}$ values, due to the systematic decrease in surface temperature at higher elevations as a result of adiabatic cooling effects. This covariance leads to the testable hypothesis that carbonates precipitated at highelevation sites will be characterized by colder carbonate growth temperatures than contemporaneous carbonates formed at lower elevations, assuming carbonate growth occurs over equivalent times of the year and local climatic variations 
do not supersede elevation effects. This temperature-based paleoaltimetry application of clumped isotope thermometry can be an especially powerful tool in settings where the violation of Rayleigh distillation rainout processes significantly limits the application of standard stable isotope paleoaltimetry techniques. For example, regions with complex isotopeelevation relationships (e.g., continental interior of the western U.S. [Ingraham and Taylor, 1991; Friedman et al., 2002; Lechler and Niemi, 2011a] and Tibetan Plateau [e.g., Hren et al., 2009; Quade et al., 2011; Lechler and Niemi, 2011a]) and areas where surface waters are subject to evaporative influence are prone to producing stable isotope-based paleoelevation estimates with significant uncertainties [e.g., Quade et al., 2007; Lechler and Niemi, 2012].

[10] Huntington et al. [2010] applied the carbonate clumped isotope thermometry technique to suites of modern and ancient carbonates collected over an elevation range of $\sim 2 \mathrm{~km}$ in the Colorado Plateau region of the western U.S. in order to investigate the middle to late Neogene paleoelevation and paleoclimate history of the region. In that study, similar $\Delta_{47}$ temperature-elevation gradients for both modern and Miocene carbonates were interpreted as indicating that middle Miocene paleoelevations and paleotopographic gradients were comparable to the modern [Huntington et al., 2010]. Here we implement carbonate clumped isotope thermometry to constrain the paleotopography of the Late Cretaceous-early Paleogene northern Basin and Range and middle Miocene central Basin and Range.

\section{Regional Geology and Lacustrine Basin Sampling}

\subsection{Late Cretaceous-Early Paleogene Basins}

[11] The western U.S. Cordillera was subject to oceanic subduction and associated compressive stresses throughout much of the Mesozoic and early Cenozoic Sevier and Laramide orogenies [e.g., Sonder and Jones, 1999, and references therein], resulting in a spatially extensive orogen bounded on its western margin by the Sierra Nevada magmatic arc. During Late Cretaceous-early Paleogene time, synconvergent extension in both the magmatic arc region [e.g., Wood and Saleeby, 1997] and the deformed foreland [e.g., Wells et al., 1990; Hodges and Walker, 1992; Wells and Hoisch, 2008] created a series of local rift basins that preserve some of the oldest Cenozoic sedimentary rocks in the western U.S. Immediately east of the southernmost Sierra Nevada, these early Cenozoic sedimentary units are represented by the Paleocene Goler Formation, which crops out in the El Paso Mountains of southeastern California (Figure 1). The Goler Formation is a $>4 \mathrm{~km}$ thick continental clastic sequence of predominantly alluvial and fluvial sandstones and conglomerates [Cox, 1982] derived from source regions in the arc flank of the eastern Sierra Nevada [Lechler and Niemi, 2011b]. The Goler Formation also contains a diverse fossil assemblage (ray teeth, crocodiles, turtles, primates, conodonts), which, in combination with the presence of marine mudstones and molluscs in the uppermost Goler Formation, indicates that the Goler basin resided at or near sea level throughout the early Paleogene [e.g., Lofgren et al., 2008]. This fossil assemblage also provides depositional age constraints, indicating that the upper Goler Formation was deposited during the middle
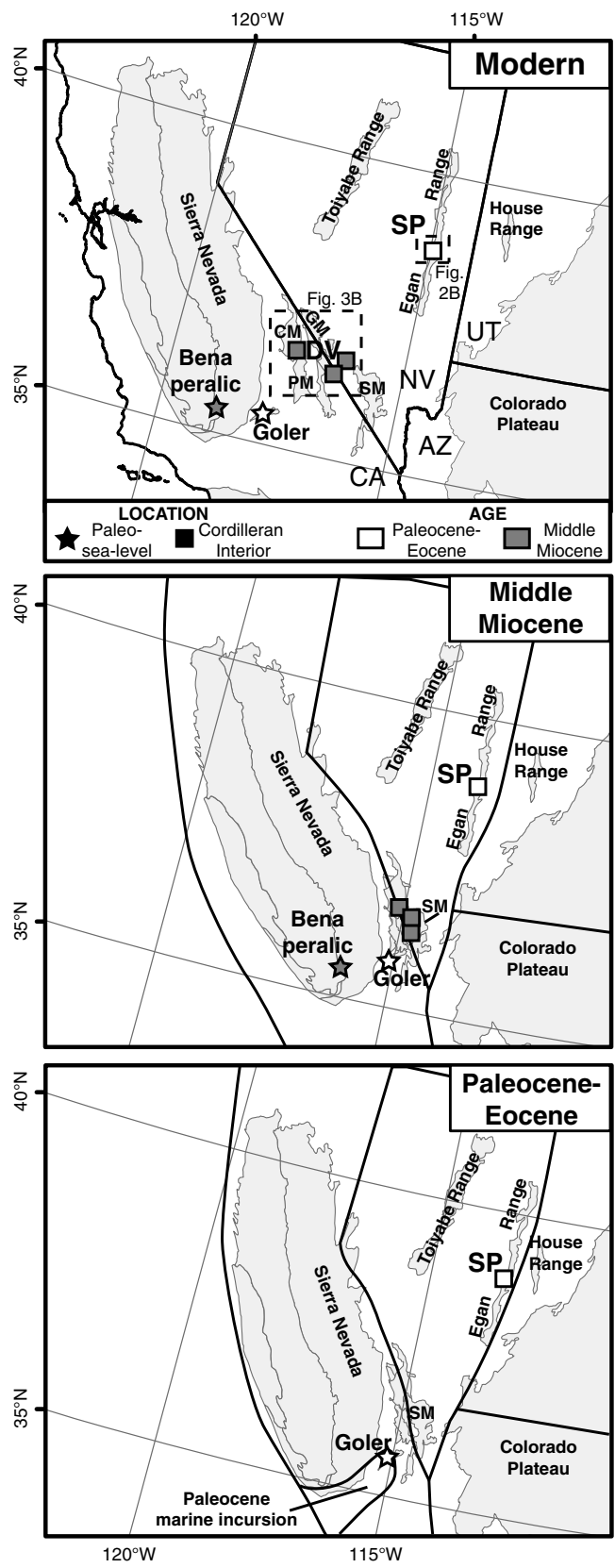

Figure 1. Spatial distribution of lacustrine carbonate sample locations throughout the Cenozoic. Upper map shows carbonate sample locations in modern geographic coordinates with major physiographic provinces and ranges of the western U.S. shown in light gray. Middle Miocene $(\sim 16 \mathrm{Ma})$ and Paleocene-Eocene (pre-36 Ma) distribution of sample sites shown in middle and bottom maps, respectively. Changes in the relative positions of physiographic provinces and mountain ranges show the timing and degree of extension throughout the western U.S. Cordilleran interior. Note that widespread crustal extension does not initiate until the post-middle Miocene in the central Basin and Range. Retrodeformed state boundaries and positions of physiographic provinces are derived from palinspastic reconstructions of McQuarrie and Wernicke [2005]. SP=Sheep Pass Formation, Goler= Goler Formation, DV = Death Valley, GM= Grapevine Mountains, $\mathrm{SM}=$ Spring Mountains, $\mathrm{PM}=$ Panamint Range, $\mathrm{CM}=$ Cottonwood Mountains. 


\section{LECHLER ET AL.: $\Delta_{47}$ PALEOALTIMETRY OF BASIN AND RANGE}

and late Paleocene (Torrejonian and Tiffanian North American Land Mammal Ages [NALMA]) [Lofgren et al., 2008]. Recent magnetostratigraphic constraints have placed more definitive bounds of $\sim 62-57.5 \mathrm{Ma}$ for the timing of Goler Formation deposition [Albright et al., 2009].

[12] Late Cretaceous-early Paleogene synconvergent extension also produced a series of extensional basins within the interior of the Cordilleran orogen [Wells and Hoisch, 2008; Druschke et al., 2009a, 2009b]. The Late Cretaceous-Eocene Sheep Pass Formation is an alluvial, fluvial, and lacustrine sedimentary sequence deposited on the hanging wall of one of these grabens. The $>1 \mathrm{~km}$ thick Sheep Pass Formation is currently exposed in the Pancake, Grant, and southern Egan ranges of east central Nevada (Figure 1) and provides one of the earliest records of extension-related sedimentary basin formation in the continental interior of the western U.S. [Druschke et al., 2009a, 2009b]. Previous workers have subdivided the Sheep Pass Formation into six lithologic members (A-F; Figure 2) [Fouch, 1979; Druschke et al., 2009b]. Clastic-dominated alluvial fan and distal alluvial fan/marginal lacustrine facies characterize Members A and C, respectively, whereas carbonate-dominated sedimentary rocks in Members B and D-F are interpreted to have been deposited in lacustrine environments [e.g., Fouch, 1979;
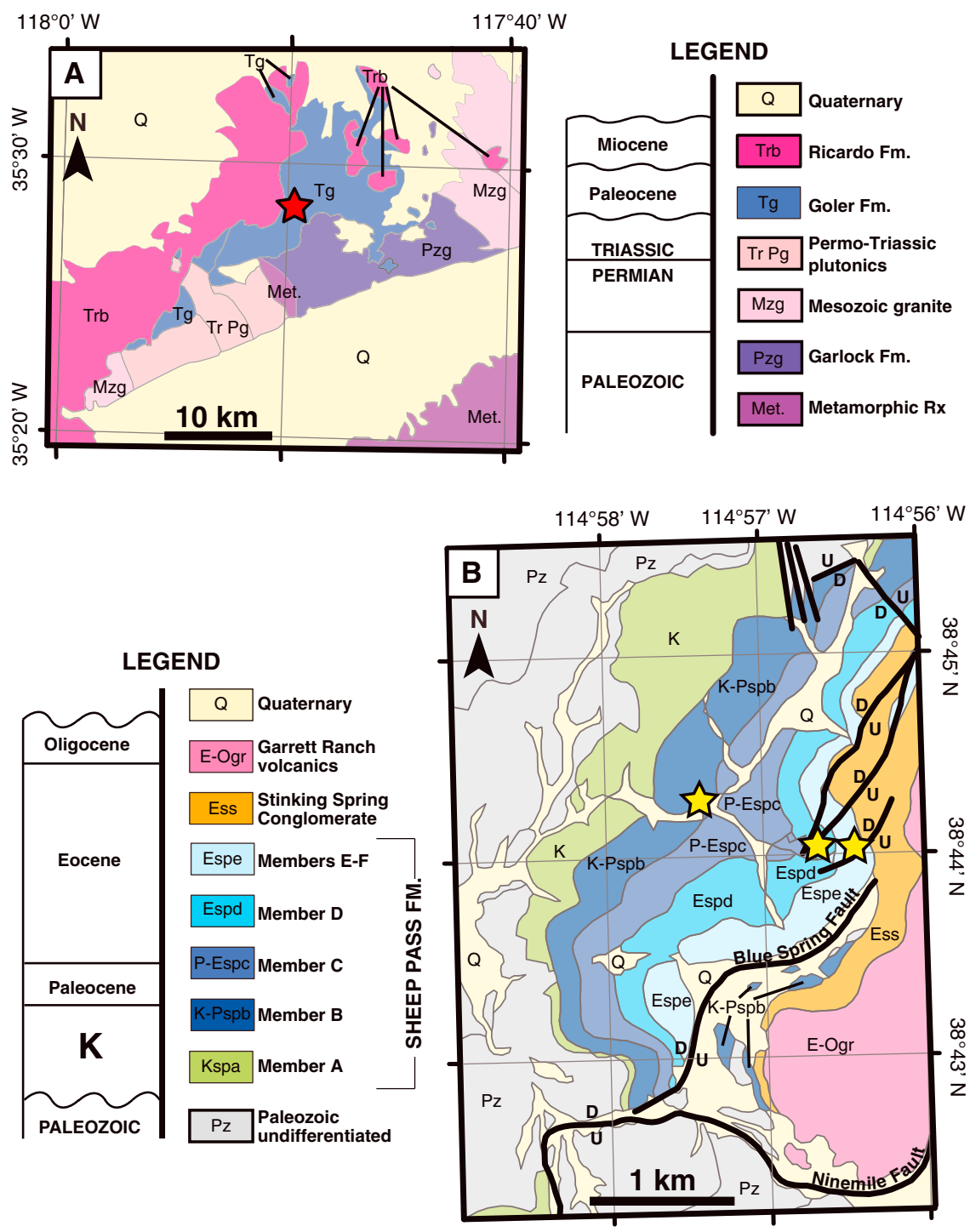

Figure 2. Geologic setting of Sheep Pass and Goler Formations carbonate sample locations. (a) Geologic map of the El Paso Mountains of southeastern California [modified from Cox, 1982]. The Paleocene Goler Formation unconformably overlies metamorphic rocks of the Paleozoic Garlock Formation and Mesozoic plutonic rocks associated with the onset of regional Sierra Nevada arc magmatism and is unconformably overlain by Miocene Ricardo Formation volcanics. Red star marks location of Goler Formation Member 4a micritic carbonate sample. (b) Detailed geology of Sheep Pass Canyon, southern Egan Range, NV, where the type section of the Late Cretaceous-Eocene Sheep Pass Formation is exposed [modified from Druschke et al., 2009b]. Yellow stars mark Sheep Pass carbonate sample locations. Both lacustrine carbonate and fossil mollusc shells were collected from the same location within Member B (K-Pspb). See Figure 1 for additional location information. 
Druschke et al., 2009b]. Molluscan specimens throughout Members B, C, and E suggest the Sheep Pass basin evolved from a single, regionally extensive lake environment into a series of isolated and ephemeral ponds in a wetland terrain through the early Paleogene [Good, 1987]. The Sheep Pass Formation has a maximum depositional age of $81.3 \pm 3.7 \mathrm{Ma}$ and a minimum age of $37.7 \pm 0.6 \mathrm{Ma}$ based on recent $\mathrm{U}-\mathrm{Pb}$ detrital zircon dating in the middle of Sheep Pass Member A and in the Stinking Springs Conglomerate member of the Garrett Ranch Group which overlies the Sheep Pass Formation [Druschke et al., 2009b]. U-Pb carbonate dating at the base of Sheep Pass Member B [Druschke et al., 2009a], in combination with biostratigraphic study of molluscan fossil assemblages in Members B and C [Good, 1987], suggests a late Campanian through Early Paleocene ( 71.5-61 Ma) age for Member B. Molluscan biostratigraphy [Good, 1987] also constrains the depositional ages of Members $\mathrm{C}$ (middle to late Paleocene, $61-55 \mathrm{Ma}$ ), D (early Eocene, 55-50 Ma), and $\mathrm{E}$ (early to middle Eocene, $\sim 50-46 \mathrm{Ma}$ ).

[13] For this clumped isotope thermometry study, carbonate samples were collected from both Goler and Sheep Pass Formations (Figures 1 and 2). Clastic sediments dominate much of the Goler Formation, but a single micritic limestone lens (1-2 m thick), believed to represent an areally restricted pond in the floodplain of a braided river system that traversed the Goler basin [Cox, 1982], is found within the upper Goler Formation (Member 4a) [Cox, 1982] and was sampled as part of this study (Figure 2a). Lacustrine micrite samples were also collected from Sheep Pass Members B and E, and a dolomite sample was collected from Member D. The sample from Member B also contained abundant fossil molluscs (Unionid bivalves) that were analyzed as part of this study. All Sheep Pass Formation samples were collected from the type section, which is exposed in Sheep Pass Canyon in the southern Egan Range (Figure 2b).

\subsection{Middle Miocene Death Valley Region}

[14] The preextensional central Basin and Range was characterized by an east-vergent thrust system, developed within the Cordilleran miogeocline, that was bordered by the Sierran arc and relatively undeformed Colorado Plateau on its western and eastern margins, respectively [e.g., Wernicke et al., 1988; Snow and Wernicke, 2000]. Unlike the northern and southern Basin and Range subprovinces where widespread crustal extension began in the Paleogene [e.g., Sonder and Jones, 1999], significant upper crustal extension did not initiate in the central Basin and Range (modern latitudes of $\sim 35^{\circ} \mathrm{N}-37^{\circ} \mathrm{N}$ ) until the middle Miocene [e.g., Wernicke, 1992; Sonder and Jones, 1999; Niemi et al., 2001; McQuarrie and Wernicke, 2005]. Despite this late onset, the central Basin and Range (CBR) has experienced the highest magnitudes of upper crustal extension of any Basin and Range subprovince, with $>100 \%$ extension more than doubling the pre-middle Miocene width of the region (Figure 1) [e.g., Snow and Wernicke, 2000; McQuarrie and Wernicke, 2005]. The timing of high-magnitude crustal extension, however, was not uniform throughout the central Basin and Range but, instead, migrated from east (i.e., Lake Mead domain) to west (i.e., Death Valley domain) [Wernicke et al., 1988; Wernicke, 1992]. While significant upper crustal extension and associated strike-slip faulting did not initiate in the Death Valley domain until post
15-12 Ma [e.g., Snow and Lux, 1999; Snow and Wernicke, 2000; Niemi et al., 2001; Fridrich and Thompson, 2011; Niemi, 2013, Renik and Christie-Blick, 2013], Oligocene to middle Miocene sedimentary sequences preserved in the Death Valley area mark an interval of minor early extension and associated sedimentary basin development [e.g., Reynolds, 1969; Snow and Lux, 1999; Fridrich and Thompson, 2011]. Although most Oligocene-Miocene sedimentary sequences in the Death Valley region are dominated by clastic, volcaniclastic, and tuffaceous sediments [see Snow and Lux [1999] and Fridrich and Thompson [2011] for detailed stratigraphy], minor lacustrine carbonate deposition is preserved in limited outcrop locations throughout the Death Valley area (Figure 3). Lacustrine carbonates were sampled from three of these early to middle Miocene basins for stable and clumped isotope analysis.

[15] Lacustrine facies in Member 4 of the Oligocene-early Miocene Ubehebe Formation contain pisolites that are up to $2 \mathrm{~cm}$ in diameter and $5 \mathrm{~cm}$ long and are indicative of littoral conditions in a freshwater lake environment [Snow and Lux, 1999]. Radiometric dates from tuffs that bound the pisolitebearing lacustrine interval constrain lacustrine deposition to 19.6-15.7 Ma [Snow and Lux, 1999; Fridrich and Thompson, 2011]. Samples of these pisolites were collected from Marble Canyon in the Cottonwood Mountains, which form the northwestern boundary of modern-day Death Valley (Figure 3).

[16] Lacustrine carbonate samples were also collected from the middle Miocene Rocks of Pavits Spring, which crops out in Amargosa Valley, east of Death Valley (Figure 3), and the middle Miocene Kelley's Well Limestone member of the early to middle Miocene (21.2-13.5 Ma) Bat Mountain Formation, which is exposed in the southernmost Funeral Mountains (Figure 3). Published isotopic $\left(\delta^{18} \mathrm{O}\right.$ and $\left.\delta^{13} \mathrm{C}\right)$ records for the Kelley's Well Limestone (hereafter referred to as "Bat Mountain limestone") have been previously reported as part of regional paleoelevation studies [Horton and Chamberlain, 2006] and provide a point of reference for the isotopic analyses presented here.

[17] We also collected a contemporaneous carbonate sample formed at a near-sea level paleoelevation for comparison with the middle Miocene Death Valley area lacustrine carbonate samples. This middle Miocene sea level carbonate was sampled from the peralic facies of the Bena Gravels that crop out near Cottonwood Creek at the western base of the southern Sierra Nevada (Figure 3). The Bena Gravel peralic facies sequence is immediately under- and overlain by pebble-cobble conglomerates of the alluvial fan facies of the Bena Gravels and consists of marine, brackish, and freshwater siliciclastic and carbonate rocks [Bartow and MacDougall, 1984] indicative of a near-sea level basin that was alternately inundated by and restricted from marine waters. Marine diatoms within the peralic interval indicate a middle Miocene (Langhian foraminfera stage) age of $\sim 16-14 \mathrm{Ma}$ for the Bena peralic facies [Bartow and MacDougall, 1984].

\section{Analytical Methods}

[18] Carbonate sample preparation and isotopic analyses were completed at the University of Michigan (UM) Stable Isotope Laboratory. All samples were analyzed for both standard stable $\left(\delta^{18} \mathrm{O}\right.$ and $\left.\delta^{13} \mathrm{C}\right)$ and clumped $\left(\Delta_{47}\right)$ isotopic compositions. Carbonate samples were drilled following 


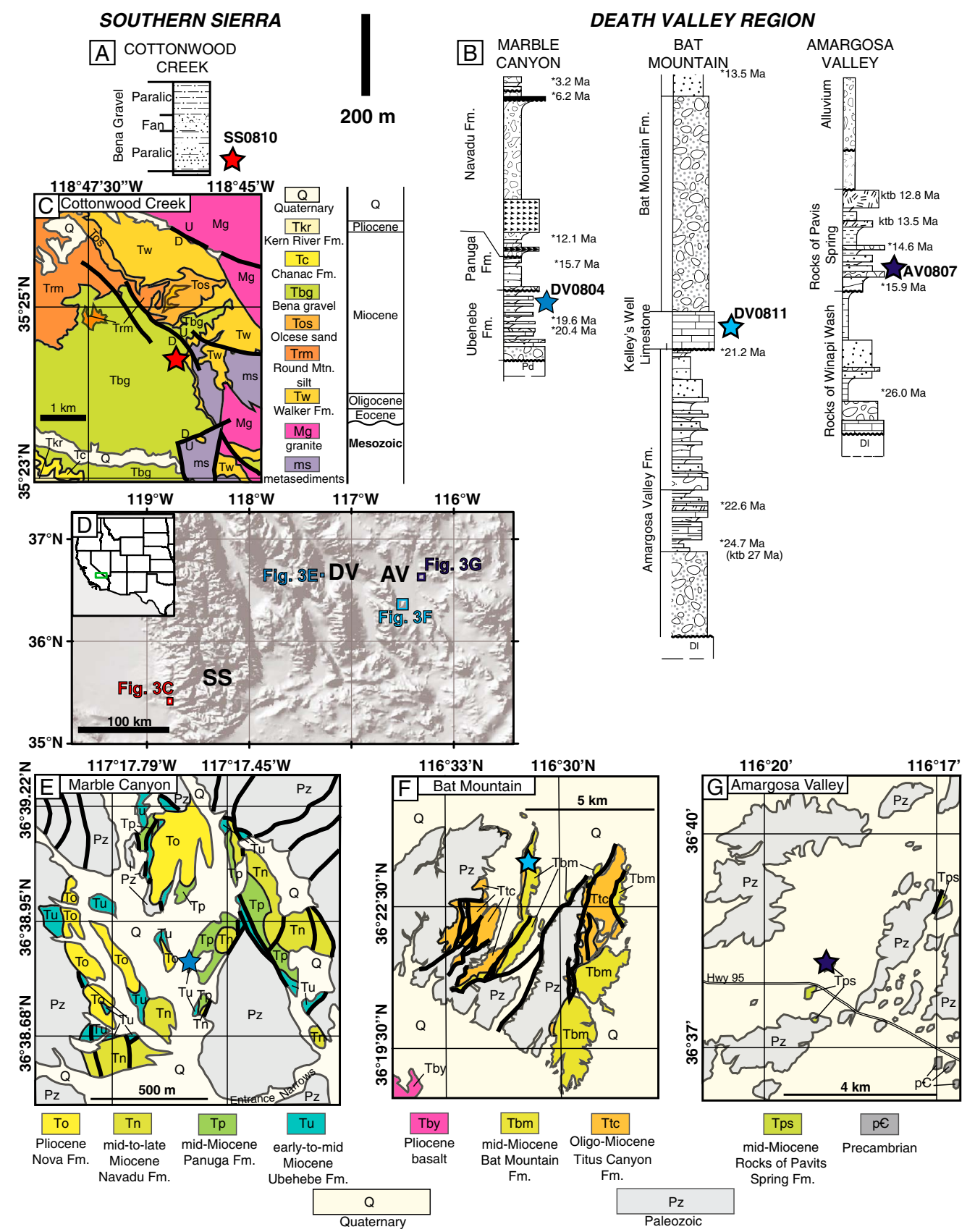

Figure 3. (a) Stratigraphic column for Bena Gravels which crop out in the southern Sierra Nevada (Cottonwood Creek) [Bartow and McDougall, 1984]. (b) Stratigraphic columns for sampled Neogene sedimentary basins in the Death Valley region with marker beds and associated radiometric ages labeled (simplified from Fridrich and Thompson [2011, and references therein]). Two hundred meters stratigraphic scale bar applicable to both Figures 3a and 3b. (c) Simplified geologic map of the Cottonwood Creek area of the southern Sierra Nevada where the peralic facies of the Bena Gravels were sampled (red star) [modified from Bartow, 1981]. (d) Hillshade map of the southern Sierra Nevada-Death Valley region with extents of simplified geologic maps of Cottonwood Creek in Figure 3c, Marble Canyon in Figure 3e, Bat Mountain in Figure 3f, and Amargosa Valley in Figure 3g. Map extents are outlined and color coded by sample localities, as shown in stratigraphic columns in Figures $3 \mathrm{a}$ and $3 \mathrm{~b}$. Inset shows location and extent of hillshade map. SS = southern Sierra Nevada, DV = Death Valley, AV = Amargosa Valley. (e) Simplified geologic map of the Marble Canyon area of the Cottonwood Mountains [modified from Snow and Lux, 1999] with sample location of Ubehebe Formation pisolites marked by blue star. (f) Simplified geologic map of the Bat Mountain area of the Funeral Mountains [modified from Fridrich et al., 2008], where the Kelley's Well Limestone member of the Bat Mountain Formation was sampled (light blue star). (g) Simplified geologic map of the Amargosa Valley area where the Rocks of Pavits Spring were sampled (purple star) [simplified from Burchfiel, 1966]. Thick, black lines on geologic maps mark mapped surface faults. 
standard micromilling procedures [Dettman and Lohmann, 1995]. For $\delta^{18} \mathrm{O}$ and $\delta^{13} \mathrm{C}$ measurements, $\sim 1 \mathrm{mg}$ of drilled carbonate powder for each sample was placed under vacuum at $200^{\circ} \mathrm{C}$ for $1 \mathrm{~h}$ to remove volatile contaminants and water. Samples were then placed in individual borosilicate reaction vessels and reacted at $75^{\circ} \mathrm{C} \pm 1^{\circ} \mathrm{C}$ with four drops of anhydrous phosphoric acid for $8 \mathrm{~min}$ in a Finnigan MAT Kiel IV preparation device coupled directly to the inlet of a Finnigan MAT 253 triple collector isotope ratio mass spectrometer. Measured precision is $<0.1 \%$ for both $\delta^{18} \mathrm{O}$ and $\delta^{13} \mathrm{C}$.

[19] For clumped isotope analyses, a specific $\mathrm{CO}_{2}$ extraction procedure is required in order to ensure purity of analyte $\mathrm{CO}_{2}$ gas [Huntington et al., 2009]. Approximately $5 \mathrm{mg}$ of drilled carbonate powder was loaded into a rotary, multisample carousel that dropped individual powder samples into a common acid bath composed of $\sim 20 \mathrm{ml}$ of anhydrous phosphoric acid that was held at a constant temperature of $75^{\circ} \mathrm{C}$ via a circulating water bath. $\mathrm{CO}_{2}$ was produced by reacting carbonate powders for $30 \mathrm{~min}$, or until completion, at $75^{\circ} \mathrm{C}$. The $\mathrm{CO}_{2}$ purification process followed the cryogenic procedures under vacuum conditions outlined in Ghosh et al. [2006a] and Huntington et al. [2009] to remove residual water vapor and other contaminants. To eliminate hydrocarbon and halocarbon contaminants for the Paleogene samples (January 2011 analysis), $\mathrm{CO}_{2}$ gas was entrained in a $\mathrm{He}$ carrier gas that flowed at a rate of $2 \mathrm{ml} / \mathrm{min}$ through a HP 5890 gas chromatograph (GC) column (Supel-Q-PLOT with $530 \mu \mathrm{m}$ i.d., $30 \mathrm{~m}$ long) held at $-20^{\circ} \mathrm{C}$ for $40 \mathrm{~min}$. After flowing through the GC column, $\mathrm{CO}_{2}$ was frozen out in a liquid $\mathrm{N}_{2}$ cold trap, and He carrier gas was pumped away. To eliminate these contaminants in the Miocene samples (July 2011 analysis), $\mathrm{CO}_{2}$ gas was purified by passing it through Porapak material, which was held at $\sim-20^{\circ} \mathrm{C}$, for $15 \mathrm{~min} . \mathrm{CO}_{2}$ pressure was measured prior to and following the GC/Porapak purification steps in order to ensure constant yields. In both cases, purified $\mathrm{CO}_{2}$ then went through two subsequent cryogenic purification cycles and was eventually trapped in an evacuated glass vessel and transferred for isotopologue analysis. Comparison of working standards and samples that required a high degree of "cleaning" shows no difference between the $\mathrm{GC}$ and Porapak ${ }^{\mathrm{TM}}$ methods.

[20] $\mathrm{CO}_{2}$ masses 45-49 were measured on a dual-inlet Thermo-Finnigan MAT 253 mass spectrometer following the methods of Eiler and Schauble [2004]. Normalized $\Delta_{47}$ values were calculated using the stochastic reference heated gas and $\mathrm{CO}_{2}$-water equilibration lines produced during the corresponding analysis period (January or July 2011). Heated gases with stochastic isotopologue distributions were produced by heating $\mathrm{CO}_{2}$ gases of variable isotopic compositions in a muffle furnace at $1000^{\circ} \mathrm{C}$ for $2 \mathrm{~h}$. The heated gas reference lines for each of our analysis periods are shown in Figures 4 and 5. Each isotopologue analysis requires $\sim 3 \mathrm{~h}$ of mass spectrometer time in order to achieve precisions on the order of $10^{-6}$ for $\Delta_{47}$ values, and each carbonate sample was subject to at least triplicate analysis in order to reduce temperature uncertainties to values as low as $\sim \pm 1.5^{\circ} \mathrm{C}$ (1 S.E.). Final temperature values were corrected for empirically determined acid fractionation factors at $75^{\circ} \mathrm{C}$ (Table 1) and constrained by both intralaboratory (Huron River mussel, Jolters ooids) and interlaboratory (Carrara marble) carbonate standards.

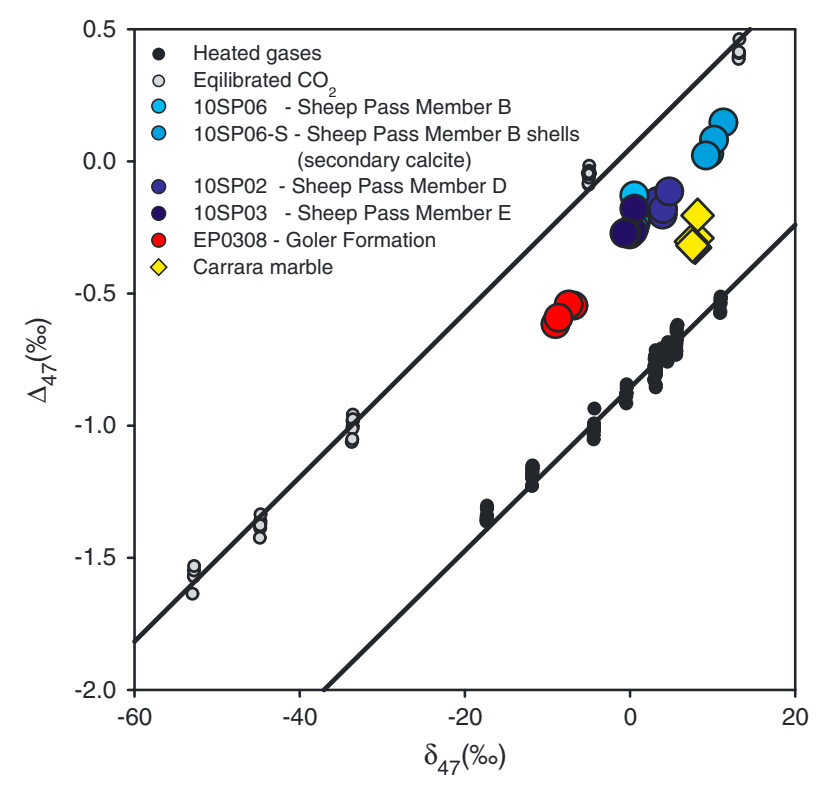

Figure 4. Heated gas line and isotopologue data. $\Delta_{47}$ versus $\delta_{47}$ for Goler and Sheep Pass carbonate samples, the Carrara marble interlaboratory carbonate standard, heated $\mathrm{CO}_{2}$ gases, and equilibrated $\mathrm{H}_{2} \mathrm{O}-\mathrm{CO}_{2}$. Linear regression of heated gas isotopologue values includes analyses of heated $\mathrm{CO}_{2}$ gases with $\delta_{47}$ values ranging from $-54 \%$ to $10 \%$. $\Delta_{47}$ values were calculated following the methodology of Dennis et al. [2011]. See Table 1 caption for additional details. Note that Sheep Pass Member B shells are composed of secondary calcite (see text for discussion).

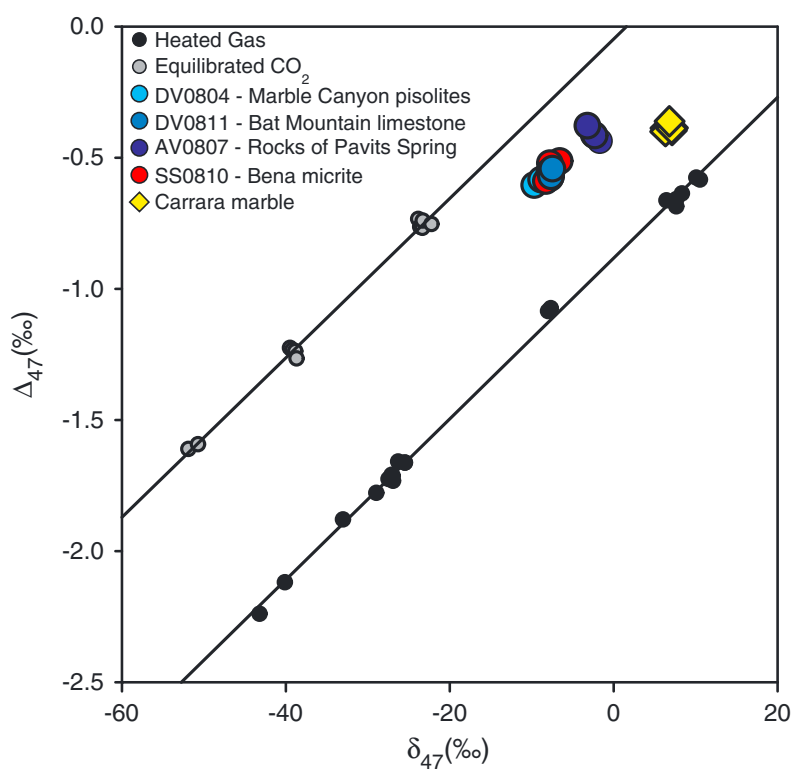

Figure 5. Heated gas line and isotopologue data for middle Miocene carbonate samples from the Bena Gravels and Death Valley area basins. See Figure 4 caption for details.

[21] We present $\Delta_{47}$ carbonate growth temperatures for two $\Delta_{47}$-temperature calibrations: (1) that of Ghosh et al. [2006a], i.e., $\Delta_{47}=59200 / T^{2}-0.02$, where $T$ is in kelvins; and (2) the recently published calibration of Dennis et al. [2011], 


\section{LECHLER ET AL:: $\Delta_{47}$ PALEOALTIMETRY OF BASIN AND RANGE}

Table 1. Summary of Clumped Isotope Thermometry and Stable Isotope Results ${ }^{\mathrm{a}}$

\begin{tabular}{|c|c|c|c|c|c|c|c|c|}
\hline \multirow{3}{*}{ Sample } & \multirow{3}{*}{$\begin{array}{c}\delta^{13} \mathrm{C}_{\mathrm{PDB}} \\
(\%)\end{array}$} & \multirow{3}{*}{$\begin{array}{c}\delta^{18} \mathrm{O}_{\text {SMOW }} \\
(\% 0)\end{array}$} & \multirow{3}{*}{$\begin{array}{l}\Delta_{47}^{\mathrm{b}} \\
(\%)\end{array}$} & \multirow{3}{*}{$\begin{array}{l}T\left({ }^{\circ} \mathrm{C}\right) \\
\text { Ghosh }\end{array}$} & \multirow{3}{*}{$\begin{array}{l}T\left({ }^{\circ} \mathrm{C}\right) \\
\text { Dennis }\end{array}$} & \multicolumn{3}{|c|}{ Summary } \\
\hline & & & & & & \multirow{2}{*}{$\underset{(\%)^{\mathrm{b}}}{\operatorname{Average}} \Delta_{47}$} & \multicolumn{2}{|c|}{ Average $T\left({ }^{\circ} \mathrm{C}\right)$} \\
\hline & & & & & & & Ghosh & Dennis \\
\hline \multicolumn{9}{|c|}{$\begin{array}{c}\text { Paleogene Northern Basin and Range and Southern Sierra Nevada } \\
\text { Late Cretaceous-Eocene Sheep Pass Formation }\end{array}$} \\
\hline 10SP03 & -0.1 & 23.6 & 0.673 & 33.2 & 35.1 & $0.704 \pm 0.017$ & $26.5 \pm 3.5$ & $23.7 \pm 5.9$ \\
\hline$\left(38.7339^{\circ} \mathrm{N}, 114.9409^{\circ} \mathrm{W}\right)$ & -0.1 & 23.7 & 0.753 & 16.5 & 7.0 & & & \\
\hline Member E & -0.7 & 23.3 & 0.694 & 28.5 & 26.9 & & & \\
\hline $48 \pm 2 \mathrm{Ma}$ & -0.4 & 22.8 & 0.697 & 27.9 & 25.8 & & & \\
\hline 10SP02 & 0.6 & 26.6 & 0.628 & 43.9 & 55.1 & $0.666 \pm 0.017$ & $35.0 \pm 3.9$ & $38.6 \pm 7.1$ \\
\hline$\left(38.7335^{\circ} \mathrm{N}, 114.9438^{\circ} \mathrm{W}\right)$ & 0.5 & 26.0 & 0.698 & 27.7 & 25.5 & & & \\
\hline Member D & 0.5 & 26.7 & 0.648 & 39.1 & 45.8 & \multicolumn{2}{|c|}{ Dolomite calibration $^{\mathrm{c}}$} & \\
\hline $52.5 \pm 2.5 \mathrm{Ma}$ & 0.9 & 27.0 & 0.691 & 29.1 & 27.9 & & $27.8 \pm 3.9$ & $31.4 \pm 7.1$ \\
\hline 10SP06 & 4.2 & 19.7 & 0.697 & 27.9 & 25.9 & $0.700 \pm 0.011$ & $27.3 \pm 2.3$ & $24.9 \pm 3.9$ \\
\hline$\left(38.7376^{\circ} \mathrm{N}, 114.9570^{\circ} \mathrm{W}\right)$ & 3.9 & 19.3 & 0.673 & 33.2 & 35.0 & & & \\
\hline Member B & 4.1 & 19.6 & 0.682 & 31.2 & 31.5 & & & \\
\hline \multirow[t]{2}{*}{$66.1 \pm 5.4 \mathrm{Ma}$} & 4.0 & 18.8 & 0.720 & 23.0 & 17.5 & & & \\
\hline & 4.1 & 19.0 & 0.729 & 21.3 & 14.7 & & & \\
\hline $10 \mathrm{SP} 06-\mathrm{S}^{\mathrm{d}}$ & 8.4 & 24.4 & 0.689 & 29.6 & 28.7 & $0.715 \pm 0.015$ & $24.3 \pm 3.1$ & $19.8 \pm 5.2$ \\
\hline$\left(38.7376^{\circ} \mathrm{N}, 114.9570^{\circ} \mathrm{W}\right)$ & 9.5 & 24.9 & 0.755 & 16.3 & 6.6 & & & \\
\hline Member B & 8.8 & 24.5 & 0.723 & 22.4 & 16.6 & & & \\
\hline $66.1 \pm 5.4 \mathrm{Ma}$ & 8.4 & 24.0 & 0.693 & 28.7 & 27.3 & & & \\
\hline \multicolumn{9}{|c|}{ Paleocene Goler Formation } \\
\hline $\mathbf{E P 0 8 0 3}^{\mathrm{e}}$ & -2.9 & 19.2 & 0.610 & 48.5 & 64.2 & $0.614 \pm 0.007$ & $47.5 \pm 1.7$ & $62.2 \pm 3.4^{\mathrm{e}}$ \\
\hline$\left(35.4640^{\circ} \mathrm{N}, 117.8539^{\circ} \mathrm{W}\right)$ & -3.6 & 17.6 & 0.606 & 49.5 & 66.3 & & & \\
\hline Goler micrite & -3.0 & 18.7 & 0.631 & 43.0 & 53.4 & & & \\
\hline (sea level) & -3.1 & 17.7 & 0.596 & 52.2 & 71.9 & & & \\
\hline $61 \pm 1 \mathrm{Ma}$ & -3.2 & 17.8 & 0.627 & 44.1 & 55.4 & & & \\
\hline \multicolumn{9}{|c|}{$\begin{array}{c}\text { Miocene Central Basin and Range and Southern Sierra Nevada } \\
\text { Death Valley Area }\end{array}$} \\
\hline AV0807 & -0.9 & 21.6 & 0.676 & 32.6 & 34.0 & $0.676 \pm 0.023$ & $32.8 \pm 5.0$ & $34.9 \pm 8.9$ \\
\hline$\left(36.6363^{\circ} \mathrm{N}, 116.3151^{\circ} \mathrm{W}\right)$ & -0.7 & 22.3 & 0.626 & 44.4 & 56.0 & & & \\
\hline Rocks of Pavits Spring & -0.8 & 21.7 & 0.668 & 34.3 & 37.1 & & & \\
\hline $14.5 \pm 1 \mathrm{Ma}$ & -1.0 & 20.9 & 0.736 & 19.9 & 12.5 & & & \\
\hline DV0811 & 0.5 & 14.8 & 0.671 & 33.6 & 35.8 & $0.688 \pm 0.008$ & $30.0 \pm 1.8$ & $29.5 \pm 3.2$ \\
\hline$\left(36.3898^{\circ} \mathrm{N}, 116.4710^{\circ} \mathrm{W}\right)$ & 0.7 & 14.6 & 0.702 & 26.8 & 23.9 & & & \\
\hline Bat Mtn. limestone & 0.8 & 14.7 & 0.676 & 32.5 & 33.9 & & & \\
\hline $14.7 \pm 2 \mathrm{Ma}$ & 0.9 & 14.7 & 0.702 & 26.9 & 24.1 & & & \\
\hline DV0804 & -4.7 & 18.1 & 0.706 & 26.0 & 22.6 & $0.699 \pm 0.005$ & $27.5 \pm 1.0$ & $25.2 \pm 1.8$ \\
\hline$\left(36.6471^{\circ} \mathrm{N}, 117.2929^{\circ} \mathrm{W}\right)$ & -4.0 & 18.7 & 0.690 & 29.5 & 28.5 & & & \\
\hline Marble Canyon pisolites & -4.3 & 18.5 & 0.701 & 27.0 & 24.3 & & & \\
\hline \multicolumn{9}{|c|}{ Middle Miocene Bena Peralic Facies-Southern Sierra Nevada } \\
\hline SS0810 & -6.9 & 22.3 & 0.692 & 29.0 & 27.7 & $0.701 \pm 0.012$ & $27.1 \pm 2.6$ & $24.5 \pm 4.4$ \\
\hline$\left(35.4061^{\circ} \mathrm{N}, 118.7703^{\circ} \mathrm{W}\right)$ & -6.5 & 23.1 & 0.703 & 26.6 & 23.6 & & & \\
\hline Bena micrite & -7.4 & 22.3 & 0.676 & 32.4 & 33.7 & & & \\
\hline (sea level) & -7.1 & 22.5 & 0.734 & 20.2 & 12.9 & & & \\
\hline $15 \pm 1 \mathrm{Ma}$ & & & & & & & & \\
\hline
\end{tabular}

\footnotetext{
${ }^{\text {a}}$ Stable and clumped isotope results. Stratigraphic, age, and location information provided for each sample. Average temperatures are calculated for two distinct $\Delta_{47}$-temperature calibrations: (1) Ghosh et al. [2006a] ("Ghosh") and (2) absolute reference frame (ARF) of Dennis et al. [2011] ("Dennis").

${ }^{\mathrm{b}} \Delta_{47}$ values are reported in the ARF [Dennis et al., 2011] and have been adjusted for the acid fractionation factor associated with a $75^{\circ} \mathrm{C}$ reaction temperature which was empirically determined at the University of Michigan (UM) Stable Isotope Laboratory during $\Delta_{47}$ analysis periods. Compared to $\Delta_{47}$ values for carbonate samples reacted at the accepted normal calcite reaction temperature of $25^{\circ} \mathrm{C}$ [Dennis et al., 2011], normalized $\Delta_{47}$ values of carbonates reacted at $75^{\circ} \mathrm{C}$ are 0.0670 lower. Normalization of the data for scale compression relative to the ARF and correction for acid fractionation produces mean $\Delta_{47}$ values for the UM interlaboratory standard Cararra marble of $0.397 \pm 0.007$ and $0.406 \pm 0.007$ for the January 2011 and July 2011 analysis periods, respectively. Current normalization procedure for $\Delta_{47}$ measurements at the UM Stable Isotope Laboratory are based on measurements of gases heated to $1000^{\circ} \mathrm{C}$ for $2 \mathrm{~h}$ and $\mathrm{CO}_{2}$ equilibrated with waters at $25^{\circ} \mathrm{C}$ and $50^{\circ} \mathrm{C}$ and determination of a common slope to account for instrumental scale compression.

${ }^{c}$ Temperatures for dolomite calibration reflect the calculated temperature offset $\left(\sim 7.2^{\circ} \mathrm{C}\right)$ between calcite and dolomite temperature calibrations at the averaged $\Delta_{47}$ value [equations of Guo et al., 2009].

${ }^{\mathrm{d}}$ Sheep Pass Member B shells (10SP06-S) are composed of secondary calcite and do not retain primary aragonite composition.

${ }^{\mathrm{e}}$ Calculated $\Delta_{47}$ temperatures suggest that Goler micrite likely underwent diagenetic alteration (see text for discussion).
}

which requires $\Delta_{47}$ values to be first converted to an absolute reference frame (ARF) value via a multistep correctional procedure before implementing the $\Delta_{47}$-temperature equation: $\Delta_{47}=\left(0.0636 \pm 0.0049 \times 10^{6}\right) / T^{2}-(0.0047 \pm 0.0520)$ [Dennis et al., 2011, equation (9)]. The ARF method of Dennis et al. [2011] aims to eliminate sources of interlaboratory uncertainties, such that all reported $\Delta_{47}$ values, independent of time and place of analysis, are directly comparable to one another.

[22] All carbonate samples were also subject to petrographic analysis and cathodoluminescence imaging to aid in the identification of diagenetic alteration. Such diagenesis 
can significantly alter $\Delta_{47}$ temperatures, especially in cases of high burial temperatures [e.g., Dennis and Shrag, 2010]. Assessment of diagenetic influence is particularly vital to establishing the validity of the Goler and Sheep Pass carbonates as recorders of Late Cretaceous-Paleogene terrestrial surface conditions as sediments of each formation have been subject to high temperature and/or depth burial conditions since deposition. Goler Formation carbonate was likely buried in excess of $3 \mathrm{~km}$ based on thickness estimates of the upper Goler Formation $(\sim 1.5 \mathrm{~km})[$ Cox, 1982] and overlying Miocene Ricardo Formation $(\sim 1.7 \mathrm{~km})$ [Loomis and Burbank, 1988]. In some places, the carbonates of Sheep Pass Member B experienced significant burial temperatures, possibly in excess of $400^{\circ} \mathrm{C}$ locally [Ahdyar, 2011], making them vital source rocks for oil generation in the Railroad Valley of eastern Nevada [e.g., Bortz and Murray, 1979; Ahdyar, 2011].

[23] X-ray diffraction (XRD) patterns of powdered carbonate samples were also analyzed in order to identify the primary mineralogy of each sample. XRD analysis confirmed that all samples analyzed for this study were calcite with the exception of the dolomite sample collected from Sheep Pass Member D (10SP02; Table 1). The calcite composition of Sheep Pass Member B shells indicates that original aragonite has not been preserved, the implications of which are discussed later herein.

\section{Clumped Isotope $\left(\Delta_{47}\right)$ Results}

[24] Stable $\left(\delta^{18} \mathrm{O}\right.$ and $\left.\delta^{13} \mathrm{C}\right)$ and clumped $\left(\Delta_{47}\right)$ isotopic results are summarized in Table 1 , and the presented $\Delta_{47}$ values are reported in the absolute reference frame of Dennis et al. [2011].

[25] Figures 4 and 5 show raw $\delta_{47}$ versus $\Delta_{47}$ values for the carbonate, heated gas, and equilibrated $\mathrm{CO}_{2}$ analyses of this study.

\subsection{Goler and Sheep Pass Formations Results}

[26] The Paleocene Goler micrite is characterized by highly reproducible $\Delta_{47}$ values $(0.0614 \% 0 \pm 0.007 \%$ ), but the resulting calculated carbonate growth temperatures vary greatly, depending on the $\Delta_{47}$-temperature calibration applied (Table 1). $\Delta_{47}$ temperatures range from $48^{\circ} \mathrm{C} \pm 2^{\circ} \mathrm{C}$ for the Ghosh et al. [2006a] calibration ("Ghosh") to $62^{\circ} \mathrm{C}$ $3^{\circ} \mathrm{C}$ for the Dennis et al. [2011] calibration ("Dennis"). Such high temperatures clearly reflect some degree of diagenesis or resetting of the primary $\Delta_{47}$ temperatures, the implications of which are discussed in section 6.1.

[27] Late Cretaceous-Paleocene (Sheep Pass Member B) and Eocene (Members D and E) carbonates from the Sheep Pass Formation are characterized by $\Delta_{47}$ temperatures that agree within uncertainty for both Ghosh and Dennis calibrations. Members B and E micritic limestones and Member $\mathrm{B}$ shells have average $\Delta_{47}$ temperatures in the range of $\sim 24^{\circ} \mathrm{C}-27^{\circ} \mathrm{C}$ (Ghosh) or $\sim 20^{\circ} \mathrm{C}-25^{\circ} \mathrm{C}$ (Dennis; Table 1) derived from average $\Delta_{47}$ values of $0.700 \% \pm 0.011 \%$ (Member B micrite), $0.715 \%$ o $\pm .015 \%$ (Member B shells), and $0.704 \%$ o $\pm .017 \%$ (Member $\mathrm{E}$ micrite). The similarity of $\Delta_{47}$ temperatures for Member B shells that have undergone primary aragonite to secondary calcite conversion to those of Members B and E micrites, which have been identified as primary calcites based on petrographic analysis and cathodoluminescence imaging, suggests that shell diagenesis occurred in the near-surface environment soon after deposition. Accordingly, we interpret Member B shells as reliable recorders of Late Cretaceous-Paleocene Sheep Pass basin climatic conditions, and therefore robust paleoelevation indicators, despite the loss of primary aragonite.

[28] Using the calcite $\Delta_{47}$-temperature calibration for Member D dolomite (sample 10SP02; average $\Delta_{47}=0.666 \%$ o $\pm 0.017 \%$ ) yields anomalously high temperature values $\left(\sim 35^{\circ} \mathrm{C}-39^{\circ} \mathrm{C}\right)$ due to not accounting for the different clumping behaviors of calcite and dolomite. Theoretical calculations by Guo et al. [2009] show that calcite and dolomite precipitated at equal temperatures will yield a $\Delta_{47}$ offset between the two phases of $\sim 0.02 \%$, in which calcite $\Delta_{47}$ is higher. Dolomite formation $\left(\Delta_{47}\right)$ temperatures can then be approximated by first accounting for this $0.02 \%$ offset and then applying standard $\Delta_{47}$-temperature calibrations [Ferry et al., 2011]. Adjusting for this compositional effect results in calculated Sheep Pass Member D dolomite growth temperatures $\left(28^{\circ} \mathrm{C} \pm 4^{\circ} \mathrm{C}-\mathrm{Ghosh} ; 31^{\circ} \mathrm{C} \pm 7\right.$ $\mathrm{C}$-Dennis) that are closer to those observed for micrites of Members B and E, particularly when calculated with the Ghosh temperature calibration (Table 1). Age-temperature plots for the Late Cretaceous-Eocene Goler and Sheep Pass carbonates are shown in Figure 6.

\subsection{Death Valley and Southern Sierra Nevada Results}

[29] Carbonate $\Delta_{47}$ and associated temperature values for middle Miocene carbonates collected from the Death Valley and southern Sierra Nevada regions are presented in Table 1 and Figure 7. Micrite from the southern Sierra Nevada Bena peralic facies yielded an average $\Delta_{47}$ value of $0.701 \%{ }_{0} \pm 0.012$ and calculated carbonate growth temperatures of $27^{\circ} \mathrm{C} \pm 3^{\circ} \mathrm{C}$ (Ghosh) and $25^{\circ} \mathrm{C} \pm 4^{\circ} \mathrm{C}$ (Dennis). Comparable $\Delta_{47}$ and temperature values were measured for the early to middle Miocene Marble Canyon pisolites $\left(\Delta_{47}=0.699 \% \pm \pm 0.005 \%\right.$; Ghosh temperature $=28^{\circ} \mathrm{C} \pm 1.0^{\circ} \mathrm{C}$; Dennis temperature $=25$ $\mathrm{C} \pm 2^{\circ} \mathrm{C}$ ), whereas slightly warmer temperature (lower $\Delta_{47}$ ) values are calculated for the Bat Mountain limestone $\left(\Delta_{47}=0.688 \% \pm 0.008 \%\right.$; Ghosh temperature $=30^{\circ} \mathrm{C} \pm 2^{\circ} \mathrm{C}$; Dennis temperature $=30^{\circ} \mathrm{C} \pm 3^{\circ} \mathrm{C}$ ) and micrite from the Rocks of Pavits Spring $\left(\Delta_{47}=0.676 \% \pm 0.023 \%\right.$; Ghosh temperature $=32^{\circ} \mathrm{C} \pm 5^{\circ} \mathrm{C}$; Dennis temperature $=35^{\circ} \mathrm{C} \pm 9^{\circ} \mathrm{C}$ ).

\subsection{Water $\delta^{18} \mathrm{O}$ Values}

[30] Carbonate clumped isotope $\left(\Delta_{47}\right)$ temperatures are presumed to record the temperature of the water in which the carbonate precipitated. As a result, basin water $\delta^{18} \mathrm{O}$ values for the lacustrine basins sampled in this study can be calculated directly. With the exception of Sheep Pass Member D dolomite, all carbonate samples are composed of calcite. Accordingly, water $\delta^{18} \mathrm{O}$ values were calculated with the equilibrium fractionation equation of Kim and O'Neil [1997], in which calculated $\Delta_{47}$ temperatures were assumed to control the water-calcite fractionation factor. For Sheep Pass Member D dolomite, the fractionation equation of Schmidt et al. [2005] was used.

[31] Calculated water $\delta^{18} \mathrm{O}_{\text {VSMOW }}$ values for the Goler micrite are $-5.7 \%$ o $\pm 0.3 \%$ and $-3.3 \%$ o $\pm 0.6 \%$ or the Ghosh and Dennis calibrations, respectively. Calculated water $\delta^{18} \mathrm{O}_{\text {VSMOw }}$ values for Sheep Pass carbonates range from $\sim-9 \%$ for Member B micrite to $\sim-4 \%$ for the calcite shells collected from the same stratigraphic interval (Figure 8). 


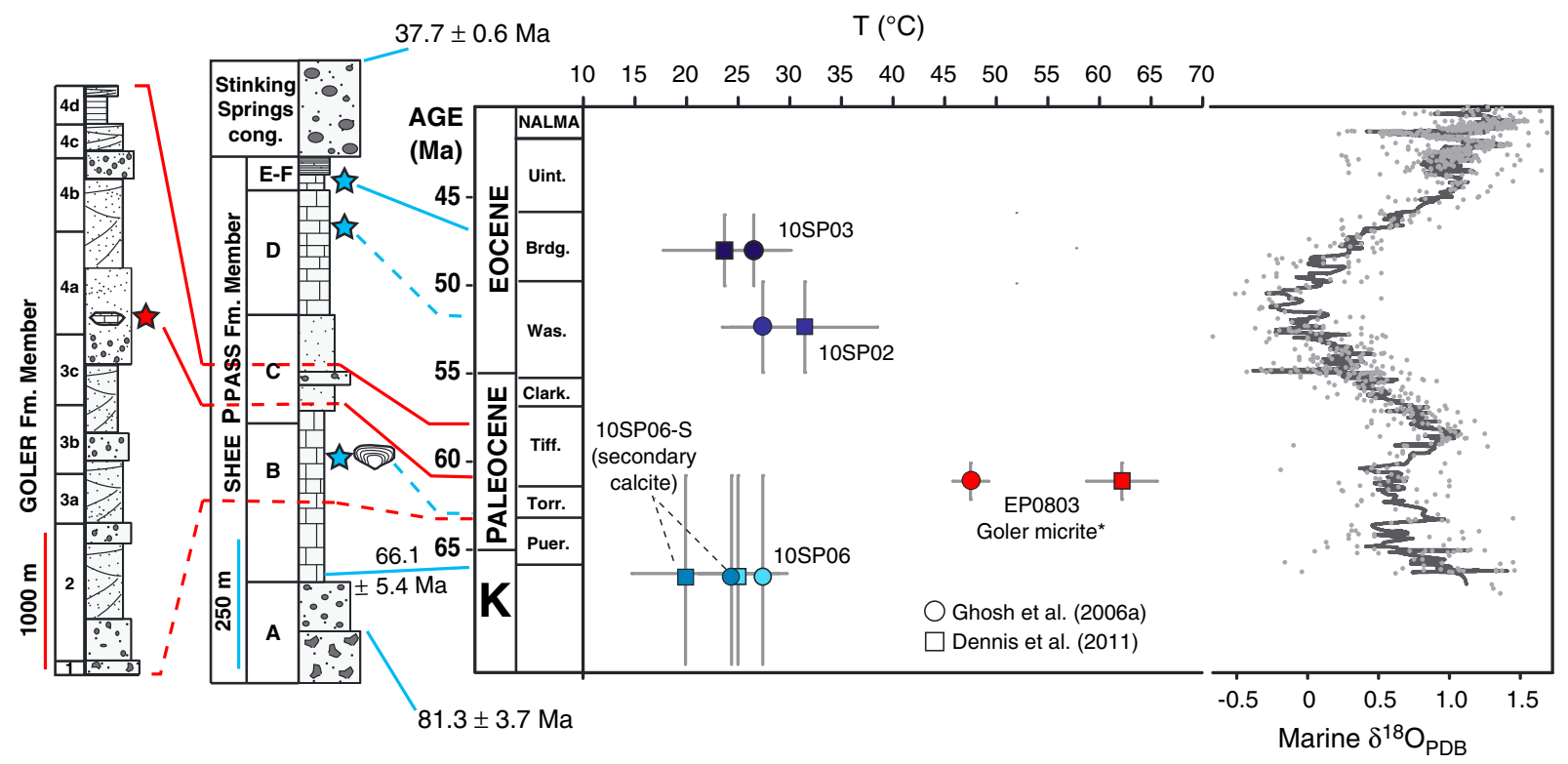

Figure 6. Age- $\Delta_{47}$ temperature plot for Goler and Sheep Pass carbonates. Zachos et al. [2001] marine $\delta^{18} \mathrm{O}$ record is shown for reference. Simplified stratigraphic columns (Goler Fm.-Cox [1982]; Sheep Pass - Fouch [1979] and Druschke et al. [2009b]) are included to provide stratigraphic correlation of the (red lines) Goler and (blue lines) Sheep Pass Formations. Dashed lines indicate approximate correlations. Stars mark approximate stratigraphic position of analyzed carbonate samples. Sampled molluscs from Sheep Pass Member B also shown. $\left(^{*}\right)$ Calculated $\Delta_{47}$ temperatures for Goler micrite indicate likely diagenetic influence (see text for discussion). North American Land Mammal Age (NALMA) assignments and age uncertainties are based on Sheep Pass molluscan biostratigraphy [Good, 1987] and radiometric dating [Druschke et al., 2009b] and Goler Formation biostratigraphy [e.g., Lofgren et al., 2008] and magnetostratigraphy [Albright et al., 2009]. NALMA abbreviations: Puer. $=$ Puercan, Torr. $=$ Torrejonian, Tiff. $=$ Tiffanian, Clark. $=$ Clarkforkian, Was. $=$ Wasatchian, Brdg. $=$ Bridgerian, Uint. $=$ Uintan.

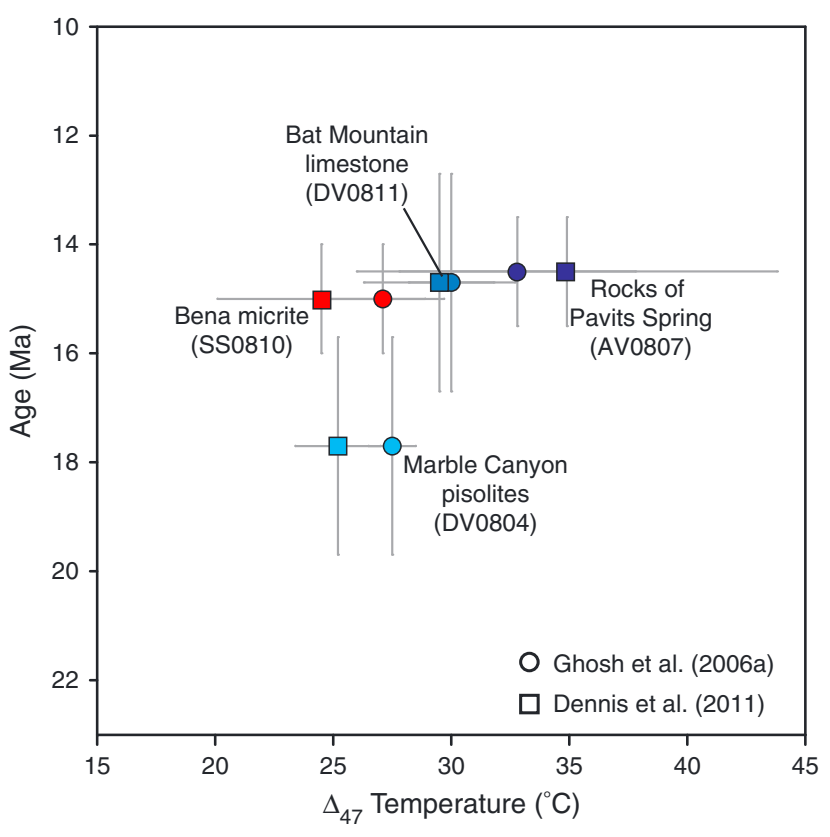

Figure 7. Age- $\Delta_{47}$ temperature plot for Bena peralic micrite and Death Valley area carbonate samples. Temperatures are plotted for $\Delta_{47}$-temperature calibrations of (circles) Ghosh et al. [2006a] and (squares) Dennis et al. [2011], as discussed in the text. Samples are color coded and labeled for clarification.
[32] Based on modern meteoric water $\delta^{18} \mathrm{O}$ distributions in the western U.S. Cordillera [e.g., Lechler and Niemi, 2011a], meteoric precipitation delivered to high-elevation $(>2 \mathrm{~km})$, continental interior lake basins, analogous to the proposed Paleogene Nevadaplano, commonly has $\delta^{18} \mathrm{O}_{\text {vsmow }}$ values $<-14 \%$. These modern values are significantly lower than the calculated water $\delta^{18} \mathrm{O}_{\text {VSMOW }}$ values for the Sheep Pass basin. The difference between calculated Paleogene Sheep Pass and observed modern regional high-elevation water $\delta^{18} \mathrm{O}_{\text {VSMow }}$ values may be due, at least in part, to reduced meteoric precipitation isotope-elevation gradients during the warmer Paleogene paleoclimate [Poulsen and Jeffrey, 2011]. However, the moderate-to-high $\delta^{18} \mathrm{O}_{\text {VSMow }}$ values for Sheep Pass basin lake waters, in combination with high Sheep Pass carbonate $\delta^{13} C_{\text {PDB }}$ values ( $-0.7 \%$ to $9.5 \%$; Table 1 ), also suggest that evaporative processes significantly impacted Sheep Pass water $\delta^{18} \mathrm{O}$ values. Proposed evaporative influence to Paleogene Sheep Pass basin waters is consistent with interpretations of closed basin and hypersaline conditions during deposition of Sheep Pass Members D and E (Figure 8) [Good, 1987]. Such hypersaline conditions also likely promoted the growth of primary dolomite [Warthmann et al., 2000] during early Eocene deposition of Sheep Pass Member D. Evaporative influence may also explain the observed difference for both calcite and associated water $\delta^{18} \mathrm{O}$ values for Member B bivalve shells relative to micrite collected from the same stratigraphic interval. High shell 


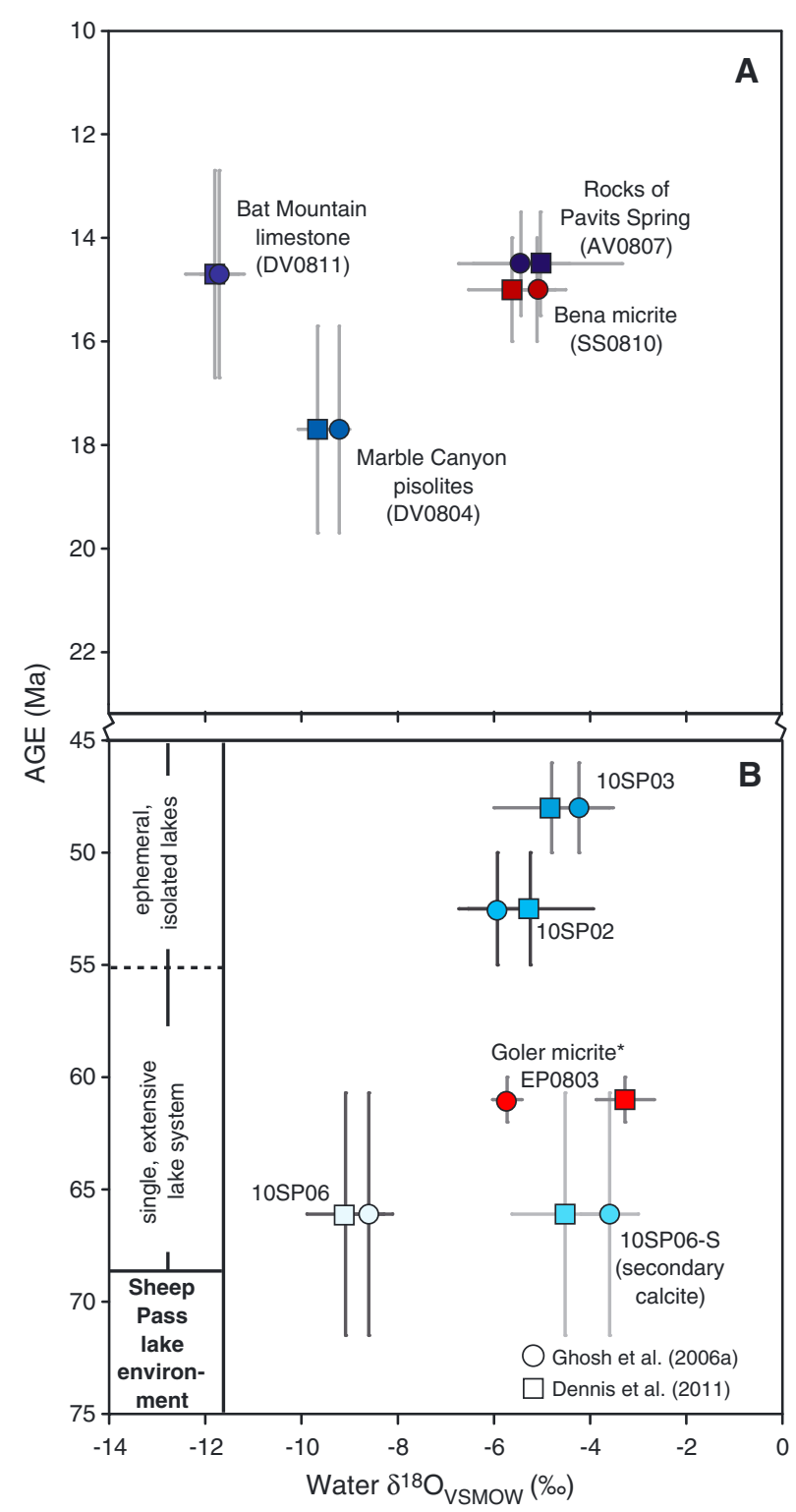

Figure 8. Water $\delta^{18} \mathrm{O}$ plots for the (a) middle Miocene Death Valley-southern Sierra Nevada and (b) Late CretaceousEocene Sheep Pass and Paleocene Goler basins. Evolution of Sheep Pass (SP) lacustrine environments ("SP lake environment") during the early Cenozoic (shown in Figure 8b) is constrained by molluscan biostratigraphy [Good, 1987]. (*) Goler micrite $\Delta_{47}$ temperatures (Table 1 and Figure 6) indicate likely diagenetic alteration.

$\delta^{18} \mathrm{O}$ values suggest that shell growth was limited to portions of the lake basin subject to maximum evaporative water loss (i.e., shallow flats), whereas micrite precipitated from less evaporatively modified lake waters. Alternatively, the lack of preservation of original aragonite in Member B bivalve shells suggests possible isotopic reequilibration with postdepositional meteoric fluids, which could also explain the distinct isotopic compositions (both $\delta^{18} \mathrm{O}$ and $\delta^{13} \mathrm{C}$ ) for Member B micrite and bivalve shells. In any case, there is strong evidence for significant evaporative influence to Sheep Pass carbonate $\delta^{18} \mathrm{O}$ and $\delta^{13} \mathrm{C}$ records. As a result, standard stable isotope paleoaltimetry methodologies that rely exclusively on proxy $\delta^{18} \mathrm{O}($ or $\delta \mathrm{D})$ compositions will be significantly limited for the Sheep Pass and similar evaporative basins due to the fact that any initial elevation signal in the meteoric precipitation delivered to the basin has been erased by postdepositional isotopic modification [e.g., Quade et al., 2007; Lechler and Niemi, 2012].

[33] For the Miocene Death Valley and southern Sierra suite of analyzed lacustrine carbonates, calculated water $\delta^{18} \mathrm{O}_{\text {VSMOW }}$ values are at a maximum for the Rocks of Pavits Spring and Bena micrite $(\sim-5 \%$ o to $-5.5 \%$; Figure 8$)$. High $\delta^{18} \mathrm{O}$ values are expected for the Bena basin due to its well-constrained near-sea level paleoelevation and proximity to the paleoPacific Coast during the middle Miocene. The high $\delta^{18} \mathrm{O}$ values for the continental interior Rocks of Pavits Spring basin, however, likely reflect evaporative influence, which is consistent with the relatively warm water temperatures constrained by $\Delta_{47}$ analysis $\left(\sim 33^{\circ} \mathrm{C}-35^{\circ} \mathrm{C}\right.$; Table 1$)$. It is less straightforward to interpret evaporative and elevation signals for the Marble Canyon pisolites $\left(\delta^{18} \mathrm{O}_{\text {VSMOW }}\right.$ $\sim-9 \%$ ) and Bat Mountain limestone $\left(\delta^{18} \mathrm{O}_{\mathrm{VSMOW}} \sim-12 \%\right.$ ) as water $\delta^{18} \mathrm{O}$ values for these basins are not particularly diagnostic. However, these basins do not appear to have been as significantly influenced by evaporation as the Rocks of Pavits Spring basin.

\section{6. $\quad \Delta_{47} T$-Mean Annual Air Temperature Calibrations}

[34] Carbonate $\Delta_{47}$ temperatures presumably record the integrated water temperature over the time in which carbonate precipitated. In the case of the lacustrine micrites analyzed for this study, the relevant water temperature reflected by $\Delta_{47}$ values is that of the surface lake waters where the carbonate formed. How these surface water temperatures relate to, as well as inform about, regional paleoclimate, remains a relatively open-ended question. Of particular interest is the relationship between $\Delta_{47}$ temperature and mean annual air temperature (MAAT), the environmental parameter most commonly determined in paleobotanical studies [e.g., Wolfe et al., 1998; Fricke and Wing, 2004]. Recent work has shown that lake water $T$-MAAT relationships are sensitive to the specific climate and physiographic setting of the lacustrine basin and that carbonate type (e.g., biotic and abiotic) and growth period (e.g., warm season and annual) significantly influence proxy-based determinations of these water-air temperature relationships [e.g., Hren and Sheldon, 2012]. The recent study of Hren and Sheldon [2012] has explicitly investigated modern lake water $T$-MAAT relationships and provided transfer functions and criteria that improve MAAT estimates derived from calculated $\Delta_{47}$ temperatures that are presumed to record a seasonal water temperature during the time of mineral growth. We apply the transfer functions of Hren and Sheldon [2012] to relate the lake water temperature during carbonate formation $\left(\Delta_{47}\right)$ to mean annual air temperature (MAAT) for the early Paleogene Sheep Pass basin and the middle Miocene Death Valley and Bena lacustrine basins (Table 2). MAAT values are not calculated for the Paleocene Goler basin due to the fact that Goler carbonate $\Delta_{47}$ temperatures $\left(>47^{\circ} \mathrm{C}\right.$; Table 1) are well outside the range of modern lake water temperatures $\left(\leq 36^{\circ} \mathrm{C}\right)$ for which the transfer functions of Hren and Sheldon [2012] were constructed, 
making Goler MAAT calculations suspect as well as potentially misleading given the likelihood of diagenetic influence on Goler micrite.

[35] The time scale of carbonate formation impacts how carbonate formation temperature relates to climate. However, the exact time scale of mineral precipitation is difficult to constrain. As a result, we use transfer functions that relate water temperature to mean annual air temperature during four potential periods of carbonate growth: annual, full warm season (April-October, AMJJASO), spring (April-June, AMJ), and peak summer (June-August, JJA). It is important to note that recent $\Delta_{47}$ studies of modern western U.S. lake carbonates suggest that carbonate growth in this region is most frequently limited to the summer when water temperatures and $\mathrm{CO}_{2}$ degassing rates are high [Huntington et al., 2010]. We suggest that transfer functions relating water and air temperatures during the warm season are most reasonable. This bias to warm season growth periods results in calculated MAAT values that are $\sim 5^{\circ} \mathrm{C}-7^{\circ} \mathrm{C}$ cooler than warm season lake-water temperatures if the AMJJASO and AMJ transfer functions are applied and up to $\sim 10^{\circ} \mathrm{C}$ cooler if calculated with the JJA transfer function (Table 2). Accordingly, MAAT estimates for the middle Miocene Death Valley region are $\sim 21^{\circ} \mathrm{C}-26^{\circ} \mathrm{C}$ (Ghosh) and $\sim 19^{\circ} \mathrm{C}-28^{\circ} \mathrm{C}$ (Dennis) when calculated with the AMJJASO and $\mathrm{AMJ}$ transfer functions and $\sim 18^{\circ} \mathrm{C}-24^{\circ} \mathrm{C}$ (Ghosh) and $\sim 15^{\circ} \mathrm{C}-26^{\circ} \mathrm{C}$ (Dennis) assuming a JJA growth period. Mean annual temperature estimates for the middle Miocene Bena basin are $\sim 17^{\circ} \mathrm{C}-22^{\circ} \mathrm{C}$ and $\sim 14^{\circ} \mathrm{C}-20^{\circ} \mathrm{C}$ for Ghosh and Dennis $\Delta_{47}$ temperatures, respectively, assuming Bena micrite formation was restricted to the warm season (Table 2). Given that Ghosh $\Delta_{47}$ temperatures are generally more precise and within error of those calculated with the Dennis calibration, as well as for simplicity, the following discussions of $\Delta_{47}$-derived Miocene MAAT trends will focus solely on values associated with the Ghosh $\Delta_{47}$-temperature calibration.

[36] The middle Miocene MAAT estimates of this study are up to $10^{\circ} \mathrm{C}$ warmer than modern MAAT in the Death Valley region. Modern MAAT is $\sim 15^{\circ} \mathrm{C}$ at Beatty, NV, located at $\sim 1000$ m.a.s.l. in the Amargosa Valley just east of Death Valley, CA, and reaches a maximum value of $\sim 25^{\circ} \mathrm{C}$ at the below-sea level elevations of Furnace Creek ( -58 m.a.s.l.) on the floor of Death Valley (Western Regional Climate Center: http://www.wrcc.dri.edu/Clumsum.html). Similarly, MAAT estimates for the middle Miocene Bena basin $\left(\sim 17^{\circ} \mathrm{C}-22^{\circ} \mathrm{C}\right)$ are up to $6^{\circ} \mathrm{C}$ warmer than modern MAAT at Santa Barbara, CA [MAAT $=16.2^{\circ} \mathrm{C}$; National Oceanic and Atmospheric Administration: http://cdo.ncdc.noaa.gov/ climtenormals/clim20/ca/04792.pdf], which is in a coastproximal, near-sea level geographic setting analogous to that of the middle Miocene Bena basin. Differences in physiographic and paleogeographic settings of middle Miocene basins in relation to the modern analogs discussed (e.g., Beatty, NV; Santa Barbara, CA) increase uncertainty of these paleo-to-modern MAAT comparisons. Despite this uncertainty, the estimated magnitude of middle Miocenemodern regional MAAT differences $\left(\leq 10^{\circ} \mathrm{C}\right)$ from this study is in general agreement with previous estimates for post$6 \mathrm{Ma}$ regional climate cooling on the order of $\sim 6^{\circ} \mathrm{C}-10^{\circ} \mathrm{C}$ in the southwestern U.S. [Huntington et al., 2010]. Application of MAAT transfer functions to the Huntington et al. [2010] 
carbonate $\Delta_{47}$ data set preserves this post-6 Ma cooling, although MAAT estimates and associated sea level air temperature intercepts are $\sim 5^{\circ} \mathrm{C}$ cooler compared to $\Delta_{47}$ temperatures and intercepts for both the modern and Miocene suites [Hren and Sheldon, 2012].

[37] MAAT estimates for the Late Cretaceous-Eocene Sheep Pass basin are $\sim 18^{\circ} \mathrm{C}-23^{\circ} \mathrm{C}$ (Ghosh) and $\sim 17^{\circ} \mathrm{C}-25^{\circ} \mathrm{C}$ (Dennis) if carbonate growth is assumed to have occurred throughout the warm season (AMJJASO) or in the springearly summer (AMJ). Sheep Pass basin MAAT could have been as low as $\sim 14^{\circ} \mathrm{C}-18^{\circ} \mathrm{C}$ (Ghosh) or $\sim 13^{\circ} \mathrm{C}-22^{\circ} \mathrm{C}$ (Dennis) if $\Delta_{47}$ temperatures reflect precipitation during a prolonged period of warm surface water temperatures (JJA), which we propose is most likely the case for Sheep Pass micrites [e.g., Huntington et al., 2010]. In contrast, modern biotic shell growth dominantly occurs during the spring-early summer (AMJ) [Hren and Sheldon, 2012, and references therein], which may explain the lower $\Delta_{47}$ temperatures for Sheep Pass Member B Unionid shells in comparison to those of Sheep Pass micrites (Table 1). Assuming JJA and AMJ growth periods for Sheep Pass micrites and shells, respectively, yields MAAT estimates of $\sim 16^{\circ} \mathrm{C}-20^{\circ} \mathrm{C}$ (Ghosh) or $\sim 13^{\circ} \mathrm{C}-22^{\circ} \mathrm{C}$ (Dennis) for the Paleogene Sheep Pass basin (Table 2). Modern MAAT in the Sheep Pass region of $\sim 7^{\circ} \mathrm{C}-8^{\circ} \mathrm{C}$ (Western Regional Climate Center) indicates that the Sheep Pass basin was significantly warmer $\left(\sim 10^{\circ} \mathrm{C}-15^{\circ} \mathrm{C}\right)$ during the early Paleogene greenhouse climate [e.g., Zachos et al., 2001]. The Sheep Pass MAAT estimates presented here are similar to paleobotanical-based MAAT estimates for the early Eocene Wind River and Green River basins of Wyoming $\left(\sim 18^{\circ} \mathrm{C}-\right.$ $25^{\circ} \mathrm{C}$ ) [Fricke and Wing, 2004] but are more than $6^{\circ} \mathrm{C}$ cooler than $\delta^{18} \mathrm{O}$-based MAAT estimates for the Late Cretaceous-Paleocene San Juan basin of northwestern New Mexico and southern Colorado $\left(\sim 28^{\circ} \mathrm{C}\right)$ [Fricke and Wing, 2004].

[38] In general, MAAT estimates are relatively uniform throughout the Sheep Pass Formation, particularly for Ghosh calibration temperatures (Table 2), which is somewhat surprising in light of well-established climate warming trends during the early Eocene Climatic Optimum (Figure 6) [Zachos et al., 2001]. A $\sim 5^{\circ} \mathrm{C}-8^{\circ} \mathrm{C}$ MAAT warming during the early Eocene deposition of Sheep Pass Member D dolomite is observed for MAAT estimates derived from the Dennis calibration (Figure 6); however, this is neither a robust nor reliable warming signal due to the fact that the dolomite $\Delta_{47}$-temperature calibration applied in this study [Guo et al., 2009] has not been calibrated to the absolute $\Delta_{47}$ reference frame of Dennis et al. [2011]. Accordingly, Sheep Pass carbonate $\Delta_{47}$ temperature and derived MAAT records do not reliably constrain the magnitudes of continental interior temperature fluctuations during the early Paleogene warm period and, instead, provide only general estimates for early Cenozoic climate conditions in the Sevier hinterland (Figure 6).

\subsection{Goler Basin Surface Temperature Reconstructions}

[39] The fact that Goler micrite $\Delta_{47}$ temperatures $\left(>47^{\circ} \mathrm{C}\right.$; Table 1) are well outside the range of modern, nonhypersaline lake surface water temperatures $\left(<36^{\circ} \mathrm{C}\right)$ [Hren and Sheldon, 2012] calls into question the reliability of the Goler micrite as a paleo-sea level temperature datum as such high $\Delta_{47}$ temperatures likely reflect at least partial diagenetic alteration or resetting. Complicating this interpretation of diagenesis, however, is the fact that both petrographic and cathodoluminescence analyses suggest that Goler micritic carbonate is primary and has not been recrystallized. In addition, preservation of lignite within the Goler Formation stratigraphically below the micritic limestone we sampled would seem to restrict postdepositional burial temperatures to $\leq 40^{\circ} \mathrm{C}$ [Koukouzas, 2007]. One possible explanation for the hot Goler micrite $\Delta_{47}$ temperatures is that these temperatures reflect low-temperature diagenetic resetting that occurred without readily observable changes in crystallinity (i.e., solid state recrystallization) [e.g., Dennis and Shrag, 2010]. In contrast, calculated Goler $\Delta_{47}$ temperatures may be anomalously high as a result of $\Delta_{47}$-temperature calibrations that remain poorly constrained for the $40^{\circ} \mathrm{C}-70^{\circ} \mathrm{C}$ range. This latter option is supported by the significant discrepancy $\left(\sim 15^{\circ} \mathrm{C}\right)$ observed for calculated Goler $\Delta_{47}$ temperatures depending on whether the Ghosh et al. [2006a] or Dennis et al. [2011] $\Delta_{47}$-temperature calibration is applied, despite identical $\Delta_{47}$ values. Unfortunately, at present, we can only speculate on the role calibration uncertainty may have played in influencing calculated Goler $\Delta_{47}$ temperatures, but, in any case, the Goler Formation micrite $\Delta_{47}$ record highlights the complications associated with reliably identifying low-temperature $\left(40^{\circ} \mathrm{C}-70^{\circ} \mathrm{C}\right)$ carbonate diagenesis, particularly in cases where observable recrystallization has not occurred.

[40] Taking Goler micrite $\Delta_{47}$ temperatures at face value suggests that Goler micritic carbonate has been likely diagenetically altered, leaving MAAT estimates for the near-sea level Paleocene Goler basin ambiguous at present. Such an interpretation points to the need for independent measures of early Paleogene terrestrial paleotemperatures along the paleo-Pacific Coast. Unfortunately, Paleocene sedimentary basins are scarce in the western U.S. Cordillera, and those that do exist (e.g., San Juan basin) are in distinct physiographic and climatic settings to that of the Goler Formation, highlighting the importance of extracting reliable paleoclimate information from the Goler basin. Future research will be directed at constraining Goler basin MAAT by utilizing the wealth of paleotemperature proxies (lignite, goethite, fossil wood, and paleosol carbonates) accessible in the Goler Formation. Specifically, extraction of lipid biomarkers for MAAT reconstruction [e.g., Hren et al., 2010], goethtite ${ }^{18} \mathrm{O} /{ }^{16} \mathrm{O}$ and $\mathrm{D} / \mathrm{H}$ thermometry [Yapp, 2008], and stable isotopic and $\Delta_{47}$ analysis of paleosol carbonates [e.g., Ghosh et al., 2006b; Quade et al., 2007, 2011] can all potentially be applied to better constrain the paleoclimatic characteristics of the Paleocene Goler basin.

\section{Paleoelevation Calculations}

[41] The utility of carbonate clumped isotope thermometry in paleoelevation studies is twofold: (1) water $\delta^{18} \mathrm{O}$ values can be calculated directly, and standard stable isotope paleoaltimetry techniques [e.g., Poage and Chamberlain, 2001; Rowley and Garzione, 2007] can be applied; and (2) paleoelevation differences can be inferred from $\Delta_{47}$-temperature comparisons of contemporary carbonates in much the same way as paleobotanical-based estimates of paleoelevation are made by applying terrestrial lapse rates (TLR) to observed temperature differences [e.g., Meyer, 2007]. 


\subsection{Death Valley Area Paleoelevations}

[42] Based on observed temperature (both $\Delta_{47}$ and MAAT) differences between the near-sea level middle Miocene Bena basin and contemporary Cordilleran interior sites in the Death Valley region, we are able to provide estimates of absolute paleoelevation for the middle Miocene Death Valley area. Paleoelevation values (Table 3 ) are calculated assuming temperature lapse rates of $4^{\circ} \mathrm{C} / \mathrm{km}$ (warm season lake water lapse rate) [Huntington et al., 2010; Hren and Sheldon, 2012] and $6^{\circ} \mathrm{C} / \mathrm{km}$ (upper bound of average air adiabatic lapse rate) [Meyer, 2007]. For both $\Delta_{47}$ temperature and MAAT comparisons, calculated paleoelevation values for most of the Miocene lake basins in the Death Valley region are $\leq 0 \mathrm{~km}$ (Table 3). These below-sea level calculated paleoelevations result from the fact that paleo-sea level Bena micrite $\Delta_{47}$ temperatures $\left(27.1^{\circ} \mathrm{C} \pm 2.6^{\circ} \mathrm{C}\right.$ - Ghosh calibration; Table 1) and calculated MAAT values $\left(\sim 17^{\circ} \mathrm{C}-22^{\circ} \mathrm{C}\right.$; Table 2$)$ are cooler than those at middle Miocene interior basin sites. These results suggest that very low paleoelevations characterized the Death Valley area prior to high-magnitude regional extension. However, this anomalous temperature pattern (i.e., minimum temperatures at the near-sea level coastal basin) may be due at least in part to coastal cooling effects. Coastal temperature depression has been proposed to have influenced carbonate $\Delta_{47}$ records from the Miocene Colorado River Basin based on observed modern temperature distributions in which lowelevation sites proximal to the Pacific Coast have MAAT $\sim 5^{\circ} \mathrm{C}-7^{\circ} \mathrm{C}$ cooler than low-elevation, inland sites that are not subject to coastal cooling effects [Huntington et al., 2010]. Accounting for a potential $5^{\circ} \mathrm{C}-7^{\circ} \mathrm{C}$ coastal temperature depression influence on Bena micrite $\left(\Delta_{47}\right.$ temperature $\sim 25^{\circ} \mathrm{C}-27^{\circ} \mathrm{C}$-Table 1 ; MAAT estimates of $\sim 17^{\circ} \mathrm{C}-22^{\circ} \mathrm{C}$ Table 2) shifts Miocene paleo-sea level $\Delta_{47}$ temperatures and MAAT estimates to higher values that are in agreement with the Miocene sea level $\Delta_{47}$ temperature intercept of Huntington et al. [2010] for the southern Colorado River Basin $\left(\sim 32^{\circ} \mathrm{C}\right)$ and the middle Miocene coastal California sea surface temperature (SST) estimates of LaRiviere et al. [2012] $\left(23^{\circ} \mathrm{C}-27^{\circ} \mathrm{C}\right)$. Adjusting for this coastal cooling effect also results in a $\sim 1-1.5 \mathrm{~km}$ increase in calculated continental interior paleoelevations, thus permitting local Miocene basin paleoelevations in the Death Valley region of up to $\sim 1.5 \mathrm{~km}$ (e.g., Marble Canyon).

\subsection{Sheep Pass Basin Paleoelevation}

[43] Hot $\Delta_{47}$ temperatures measured for Goler Formation micrite $\left(48^{\circ} \mathrm{C}\right.$ Ghosh calibration; $62^{\circ} \mathrm{C}$ Dennis calibration; Table 1) are most reasonably interpreted to reflect influence from diagenetic alteration which precludes application of this micrite as a paleo-sea level temperature datum. As a result, estimates of Sheep Pass basin paleoelevations require comparison of Sheep Pass MAAT estimates of $\sim 16^{\circ} \mathrm{C}-20^{\circ} \mathrm{C}$ (Ghosh calibration) with independent measures of early Paleogene sea level MAAT on the paleo-Pacific Coast. For these paleoelevation calculations, we use early Eocene sea level MAAT estimates of $\sim 20^{\circ} \mathrm{C}-25^{\circ} \mathrm{C}$ for the northern Sierra Nevada region $\left(\sim 38^{\circ} \mathrm{N}-40^{\circ} \mathrm{N}\right)$ that are derived from paleobotanical assemblages [Fricke and Wing, 2004], goethite ${ }^{18} \mathrm{O} /{ }^{16} \mathrm{O}$ and $\mathrm{D} / \mathrm{H}$ ratios [Yapp, 2008], and soil tetraether proxy methods [Hren et al., 2010]. The resulting MAAT difference of $\leq 9^{\circ} \mathrm{C}$ in combination with a global average terrestrial lapse rate (TLR) of $\sim 5^{\circ} \mathrm{C} / \mathrm{km}$ to $6^{\circ} \mathrm{C} / \mathrm{km}$ [Meyer, 2007] yields paleoelevation estimates of $<2 \mathrm{~km}$ for the early Paleogene Sheep Pass basin. If a lower-magnitude TLR of $\sim 4^{\circ} \mathrm{C} / \mathrm{km}$ is applied, which is plausible given the warmer, more humid climate of the early Paleogene [e.g., Zachos et al., 1994, 2001; Molnar, 2010], resulting calculated paleoelevations are on the order of $\sim 2 \mathrm{~km}$, similar to mean elevations across the modern Sheep Pass region. Such modest paleoelevations are similar to those estimated for the early Eocene Wind River and Green River basins $(\leq 1.3 \mathrm{~km})$ [Fricke and Wing [2004], where estimated MAAT values are comparable to those of the Sheep Pass basin, as discussed prior.

[44] As proposed for Miocene $\Delta_{47}$ records in this work and published studies [Huntington et al., 2010], potential coastal cooling influence on Eocene MAAT estimates for the northern Sierra Nevada coast [Fricke and Wing, 2004; Yapp, 2008; Hren et al., 2010] must be also considered. Such coastal cooling effects would have muted measured coast-

Table 3. Paleoelevation Calculations for Miocene Death Valley Region ${ }^{\mathrm{a}}$

\begin{tabular}{|c|c|c|c|c|c|c|c|c|c|c|c|c|}
\hline \multirow[b]{3}{*}{ Location/Sample } & \multicolumn{12}{|c|}{ Paleoelevation $(\mathrm{km})$ Relative to Middle Miocene Bena Peralic Facies $\left(\Delta_{47} T_{\mathrm{GHOSH}}=27.1^{\circ} \mathrm{C} \pm 1.3^{\circ} \mathrm{C}\right)$} \\
\hline & \multicolumn{6}{|c|}{$T$ Difference Used (Lapse Rate $\left.=4^{\circ} \mathrm{C} / \mathrm{km}\right)$} & \multicolumn{6}{|c|}{$T$ Difference Used (Lapse Rate $\left.=6^{\circ} \mathrm{C} / \mathrm{km}\right)$} \\
\hline & $\Delta_{47}$ & Annual & AMJJASO & AMJ & JJA & \pm & $\Delta_{47}$ & Annual & AMJJASO & AMJ & JJA & \pm \\
\hline Rocks of Pavits Spring & -1.4 & -0.4 & -1.3 & -1.1 & -1.6 & 1.6 & -0.9 & -0.3 & -0.8 & -0.8 & -1.1 & 1.1 \\
\hline Bat Mtn. limestone & -0.1 & 0.0 & -0.1 & -0.1 & -0.1 & 0.6 & -0.1 & 0.0 & -0.1 & -0.1 & -0.1 & 0.4 \\
\hline Marble Canyon pisolites & -0.7 & -0.3 & -0.7 & -0.6 & -0.8 & 0.8 & -0.5 & -0.2 & -0.4 & -0.4 & -0.6 & 0.5 \\
\hline \multirow[t]{2}{*}{ Average } & -0.7 & -0.2 & -0.7 & -0.6 & -0.9 & 1.0 & -0.5 & -0.2 & -0.4 & -0.4 & -0.6 & 0.7 \\
\hline & \multicolumn{12}{|c|}{ Paleoelevation $(\mathrm{km})$ Relative to Middle Miocene Bena Peralic Facies $\left(\Delta_{47} T_{\text {DENNIS }}=24.5^{\circ} \mathrm{C} \pm 2.2^{\circ} \mathrm{C}\right)$} \\
\hline \multirow[t]{2}{*}{ Location/Sample } & \multicolumn{6}{|c|}{$\mathrm{T}$ difference used (Lapse rate $\left.=4^{\circ} \mathrm{C} / \mathrm{km}\right)$} & \multicolumn{6}{|c|}{$\mathrm{T}$ difference used (Lapse rate $\left.=6^{\circ} \mathrm{C} / \mathrm{km}\right)$} \\
\hline & $\Delta_{47}$ & Annual & AMJJASO & AMJ & JJA & \pm & $\Delta_{47}$ & Annual & AMJJASO & AMJ & JJA & \pm \\
\hline Rocks of Pavits Spring & -2.6 & -0.8 & -2.3 & -2.1 & -3.0 & 2.8 & -1.7 & -0.5 & -1.5 & -1.4 & -2.0 & 1.9 \\
\hline Bat Mtn. limestone & -0.2 & -0.1 & -0.2 & -0.2 & -0.2 & 0.5 & -0.1 & -0.1 & -0.1 & -0.1 & -0.1 & 0.3 \\
\hline Marble Canyon pisolites & -1.3 & -0.6 & -1.2 & -1.1 & -1.5 & 0.8 & -0.8 & -0.8 & -0.8 & -0.7 & -1.0 & 0.8 \\
\hline Average & -1.3 & -0.5 & -1.2 & -1.1 & -1.6 & 1.4 & -0.9 & -0.9 & -0.8 & -0.7 & -1.0 & 1.0 \\
\hline
\end{tabular}

a Calculated "paleoelevations" for middle Miocene Death Valley region. Elevations calculated from the temperature difference between each continental interior site and the near-sea level middle Miocene Bena peralic facies for lapse rates of $4^{\circ} \mathrm{C} / \mathrm{km}$ and $6^{\circ} \mathrm{C} / \mathrm{km}$. Elevations calculated for both $\Delta_{47}$ temperature and MAAT (Annual, AMJJASO, AMJ, and JJA) differences (Table 2). All values reported in km. Uncertainty values (" \pm " column) derived from $\Delta_{47}$ temperature standard error values (Table 1). 
interior MAAT differences and thus produce anomalously low calculated paleoelevations. Applying a coastal cooling correction to Eocene paleo-Pacific Coast MAAT estimates, however, is speculative, particularly in light of the fact that much of the modern cooling along the California coast results from the cool California Current, the strength of which is sensitive to regional and global climatic changes [e.g., Herbert et al., 2001]. Accordingly, extrapolating the influence of coastal cooling effects to the early Cenozoic requires further study and is uncertain at present given the distinct greenhouse climate that characterized that time period.

\section{Discussion and Implications of Estimated Paleoelevations}

[45] Accurate quantification of uncertainties for paleoelevation estimates derived from clumped isotope thermometry, as well as standard stable isotope paleoaltimetry methods, is difficult to constrain, at least in part due to the inability to adequately quantify some of the contributing sources of uncertainty (e.g., paleotemperature lapse rates and timing of carbonate formation). Accordingly, it is safe to assume that uncertainties for reported paleoelevation values (Table 3) are significant, likely on the order of $\pm 1 \mathrm{~km}$, and similar to published studies [e.g., Huntington et al., 2010]. As a result, the paleoelevation estimates reported here can only reliably discern between gross characteristics of competing topographic, tectonic, and geodynamic models.

\subsection{Early Paleogene Northern Basin and Range}

[46] Abundant proxy paleoelevation evidence has been interpreted to suggest that the preextensional northern Basin and Range (NBR) was characterized by a high-elevation $(>3 \mathrm{~km})$ continental plateau formed as a result of long-lived Sevier contraction [Coney and Harms, 1984; Gans, 1987; Dilek and Moores, 1999; DeCelles, 2004; DeCelles and Coogan, 2006; Best et al., 2009; Ernst, 2010]. The low-to-moderate paleoelevations $(\leq 2 \mathrm{~km})$ suggested by similarity of Sheep Pass MAAT estimates in comparison to MAAT estimates for early Eocene coastal sites [Fricke and Wing, 2004; Yapp, 2008; Hren et al., 2010] implies that either (1) such an orogenic highland did not exist, or at least did not extend to the Sheep Pass region, during the early Paleogene; or (2) the relatively high carbonate growth temperatures for Sheep Pass carbonates reflect basin bottom elevations in a local, high-relief $(>1 \mathrm{~km})$ setting contained within the Nevadaplano. The latter option is consistent with recent structural and stratigraphic interpretations for the Sheep Pass basin which challenge the commonly held view that the Nevadaplano was characterized by low topographic relief [Coney and Harms, 1984; Henry, 2008; Best et al., 2009; Colgan and Henry, 2009; Cassel et al., 2012; Henry et al., 2012], specifically in the early Paleogene Sheep Pass region [Druschke et al., 2009a, 2009b].

[47] Another possible explanation for potential lowto-moderate, pre-middle Eocene paleoelevations in the Sheep Pass basin is that maximum elevations of the middle Cenozoic Nevadaplano were not attained until the late Eocene-early Oligocene, following an Eocene southward sweep of surface uplift concomitant with north-to-south removal of the Farallon slab and associated surface magmatism [e.g., Horton et al., 2004; Mix et al., 2011; Chamberlain et al., 2012]. In this model, peak Nevadaplano paleoelevations were not the direct result of Sevier contraction. The proposed topographic evolution associated with this SWEEP model (as termed by Chamberlain et al. [2012]) predicts that Paleocene-early Eocene paleoelevations throughout much of the northern Basin and Range were $\sim 1-3 \mathrm{~km}$ lower than peak elevations during late Eocene-Oligocene time. Paleobotanical-based paleoelevation estimates of $\sim 3-3.5 \mathrm{~km}$ for the late EoceneOligocene House Range flora [Gregory-Wodzicki, 1997], located proximal to the Sheep Pass region during Paleogene time $(<100 \mathrm{~km}$, Figure 1), are consistent with the SWEEP model's proposed elevation history as are stable isotope-based early Miocene paleoelevation estimates of $\sim 3.2-4.5 \mathrm{~km}$ for the nearby Snake Range [Gébelin et al., 2012]. However, neither of these paleoelevation estimates can rule out that such high regional elevations also existed throughout the early Paleogene. In addition, uncertainty about whether the observed large isotopic shifts $(\geq 6 \%)$ that act as the basis for the SWEEP uplift model truly reflect surface elevation change in the Cordilleran interior [e.g., Lechler and Niemi, 2011a], as well as the minimal amounts of paleovalley incision that occurred during the time of proposed surface uplift [Henry et al., 2012], question the validity of this Eocene surface uplift model.

[48] Unfortunately, the likelihood that diagenetic resetting influenced Goler micrite $\Delta_{47}$ temperatures leaves preextensional paleoelevations in the Sheep Pass area equivocal. Resolving the Paleogene paleoelevation history of the Sheep Pass basin will require refining our understanding of Paleocene sea level air and terrestrial surface water temperatures. As discussed above, the Goler Formation affords multiple proxies (e.g., lignite, fossil wood, and goethtite) from which these vital paleo-sea level temperature estimates can be derived in future research. Specifically, abundant paleosol carbonate sequences in the Goler Formation [Torres and Gaines, 2011] can be analyzed for $\Delta_{47}$ compositions, as we have presented here for Goler micrite, in order to constrain near-surface soil temperatures in the Paleocene Goler basin. There are known difficulties with extracting MAAT information from paleosol carbonate $\Delta_{47}$ records [e.g., Peters et al., 2012; Eiler, 2011; Quade et al., 2011], but methods for relating $\Delta_{47}$ temperatures for paleosol carbonates to MAAT are rapidly evolving [Quade et al., 2012]. As a result, $\Delta_{47}$ study of Goler Formation paleosol carbonate is a promising avenue for future research that may clarify the Goler micrite $\Delta_{47}$ records presented here.

\subsection{Middle Miocene Western Central Basin and Range}

[49] $\Delta_{47}$ temperatures and MAAT estimates for Death Valley and near-sea level southern Sierra Nevada lacustrine basins suggest that preextensional paleoelevations in the central Basin and Range-Death Valley domain were $\leq 1.5 \mathrm{~km}$ and most likely within $\sim 500 \mathrm{~m}$ of modern regional mean elevations $(\sim 1 \mathrm{~km})$ if coastal cooling effects influenced Bena micrite growth temperatures. Interpretations of middle Miocene paleorelief in the Death Valley region are also possible due to the spatial sampling of this study. The Rocks of Pavits Spring and the Bat Mountain limestone record $\Delta_{47}$ temperatures $\sim 5^{\circ} \mathrm{C}$ and $2.5^{\circ} \mathrm{C}$ warmer, respectively, than that recorded by the Marble Canyon pisolites. For a terrestrial lapse rate range of $4^{\circ} \mathrm{C} / \mathrm{km}$ to $6^{\circ} \mathrm{C} / \mathrm{km}$, these temperature differences equate to at least $\sim 0.5-1 \mathrm{~km}$ of topographic relief in the Death Valley region during the Miocene, with higher elevations in the proto-Cottonwood Mountains (Marble Canyon) than the proto-Amargosa Valley to the east. This 
proposed relief distribution is consistent with provenance studies of the middle Miocene Eagle Mountain Formation, which indicate that sedimentary source regions for depocenters in the proto-Amargosa Valley region were located in the proto-Cottonwood Mountains [Niemi et al., 2001; Niemi, 2013]. Paleorelief values of $0.5-1 \mathrm{~km}$ are minimum estimates, however, as lacustrine carbonate $\Delta_{47}$ temperatures reflect basin paleoelevations and not local peak elevations. Basin water $\delta^{18} \mathrm{O}$ values can potentially provide information about paleolake drainage basin hyspsometries [e.g., Rowley and Garzione, 2007], but only in cases where evaporative influence is minor, which is difficult to ensure for middle Miocene basins in the Death Valley region.

[50] Low regional paleoelevations in the middle Miocene Death Valley area require that elevation change concurrent with central Basin and Range extension was minor $(\leq 500 \mathrm{~m})$. This minor elevation change is surprising in light of documented regional extension amounts of $>100 \%$ [Snow and Wernicke, 2000; McQuarrie and Wernicke, 2005], which, given modern regional crustal thicknesses of $30-34 \mathrm{~km}$ [Schulte-Pelkum et al., 2011], require preextensional crustal thicknesses in excess of $60 \mathrm{~km}$, if mass was conserved during extension. In theory, isostatic compensation of such thick crust would result in high surface elevations $(>3 \mathrm{~km})$, as has been proposed for the northern Basin and Range Nevadaplano and observed in the modern Tibetan Plateau and AndeanAltiplano orogens. The fact that such high elevations are not observed in the middle Miocene Death Valley region suggests that either regional preextensional crustal thicknesses were significantly less than $60 \mathrm{~km}$, or that central Basin and Range paleoelevations were influenced by negatively buoyant gravitational forces arising from either regional lithospheric structure or dynamic mantle processes (e.g., asthenospheric downwelling). Recently published estimates for central Basin and Range lithospheric thickness and density structure have indicated that an exceptionally thick $(\sim 125 \mathrm{~km})$ dense, mantle lithosphere results in anomalously low modern mean elevations in the Basin and Range south of $\sim 37^{\circ} \mathrm{N}$ [Schulte-Pelkum et al., 2011]. It can be assumed that this thick mantle lithosphere was also present during the middle Miocene and likely contributed to the low regional middle Miocene paleoelevations estimated from regional $\Delta_{47}$ temperature and MAAT values presented in this study. In the following section, we investigate how such thick mantle lithosphere potentially influenced central Basin and Range paleoelevations and present isostatic calculations that constrain the maximum regional preextensional crustal thickness permissible by the low regional paleoelevations $(\leq 1.5 \mathrm{~km})$ proposed in this study.

\subsection{Isostatic Calculations of Central Basin and Range Paleoelevations and Modern Elevations}

[51] We test the hypothesis that low central Basin and Range paleoelevations during the middle Miocene were the result of unusually thick and dense mantle lithosphere by determining the combinations of crust and mantle thickness that can produce both modern $(\sim 1 \mathrm{~km})$ and proposed paleoelevations $(\leq 1.5 \mathrm{~km})$. Following the method of Lachenbruch and Morgan [1990], and as implemented by Schulte-Pelkum et al. [2011], we calculate the lithospheric mantle and crustal contributions to surface elevation via the following equation:

$$
\text { Elevation }(\varepsilon)=H_{\text {crust }}+H_{\text {lithosphere }}-H_{0}
$$

where $H_{0}$ is the height of a middle ocean ridge reference lithospheric column $(2.4 \mathrm{~km})$, and $H_{\text {crust }}$ and $H_{\text {lithosphere }}$ are the crustal and mantle lithosphere contributions to surface elevation, respectively. $H_{\text {crust }}$ and $H_{\text {lithosphere }}$ depend on densities and thicknesses of the crust $\left(L_{\text {crust }}\right)$ and mantle lithosphere $\left(L_{\text {lithosphere }}\right)$, respectively, for which we use the range of crustal and lithospheric mantle densities observed in the modern Death Valley region $\left(\rho_{\text {crust }}=2.7-2.8 \mathrm{~g} / \mathrm{cm}^{3}\right.$, $\rho_{\text {lithosphere }}=3.3-3.4 \mathrm{~g} / \mathrm{cm}^{3}$ ) [Schulte-Pelkum et al., 2011]. Given maximum regional lithospheric thickness of $\sim 180-240 \mathrm{~km}$ in the stable North American craton [Yuan and Romanowicz, 2010], we assume a maximum mantle lithospheric thickness $\left(L_{\text {lithosphere }}\right)$ of $200 \mathrm{~km}$ for the preextensional central Basin and Range. $H_{\text {crust }}$ and $H_{\text {lithosphere }}$ are calculated as

$$
\begin{aligned}
H_{\text {crust }}= & L_{\text {crust }} *\left(\rho_{\text {asthenosphere }}-\rho_{\text {crust }}\right) / \rho_{\text {asthenosphere }} \\
H_{\text {lithosphere }}= & L_{\text {lithosphere }} \\
& *\left(\rho_{\text {asthenosphere }}-\rho_{\text {lithosphere }}\right) / \rho_{\text {asthenosphere }}
\end{aligned}
$$

with asthenospheric density ( $\left.\rho_{\text {asthenosphere }}\right)$ calculated by the equation of England and Houseman [1989], i.e.,

$$
\rho_{\text {asthenosphere }}=\rho_{\text {lithosphere }} *\left(1-\alpha * T_{\text {asthenosphere }}\right)
$$

where $\alpha$ is the coefficient of thermal expansion for the lithosphere $\left(3.3 \times 10^{-5} / \mathrm{K}\right)$, and the temperature of the asthenosphere is set at $1333^{\circ} \mathrm{C}$.

[52] Isostatic calculation results are shown in Figure 9. Only specific combinations of crust and mantle lithosphere thicknesses and densities yield calculated mean elevations comparable to both modern $(\sim 1 \mathrm{~km})$ and estimated middle Miocene Death Valley region paleoelevations $(\leq 1.5 \mathrm{~km})$. The maximum preextensional crustal thickness associated with paleoelevations of $\leq 1.5 \mathrm{~km}$ permissible by these calculations is $\sim 48-52 \mathrm{~km}$ and is considerably less if preextensional mantle lithosphere was significantly thinner than $200 \mathrm{~km}$. Thicker preextensional crust $(>52 \mathrm{~km})$ requires crust and mantle lithosphere density combinations that, if applied to modern crust and mantle lithosphere thicknesses of 30-34 and $\sim 100-125 \mathrm{~km}$, respectively [Schulte-Pelkum et al., 2011], cannot produce modern mean elevations of $\sim 1 \mathrm{~km}$. These isostatic calculations suggest that preextensional crust in the central Basin and Range could not have exceeded $\sim 52 \mathrm{~km}$ if regional paleoelevations were $\leq 1.5 \mathrm{~km}$, as constrained by our carbonate $\Delta_{47}$ analysis. In combination with post-middle Miocene estimates of $>100 \%$ extension across the central Basin and Range [e.g., Snow and Wernicke, 2000; McQuarrie and Wernicke, 2005], these isostatic calculations indicate that mass was not conserved throughout the lithospheric column during extension. If mass conservation had occurred, modern crustal thickness across the Basin and Range would be considerably less $(<\sim 26 \mathrm{~km})$ than is observed $(\sim 30-34 \mathrm{~km})$, the implications of which are discussed below.

\section{Implications for Cenozoic Extension}

[53] Similarity $\left(\leq 9^{\circ} \mathrm{C}\right)$ of MAAT estimates derived from Late Cretaceous-Eocene Sheep Pass carbonate $\Delta_{47}$ temperatures with published MAAT estimates for the early to middle Eocene paleo-Pacific Coast [Fricke and Wing, 2004; Yapp, 

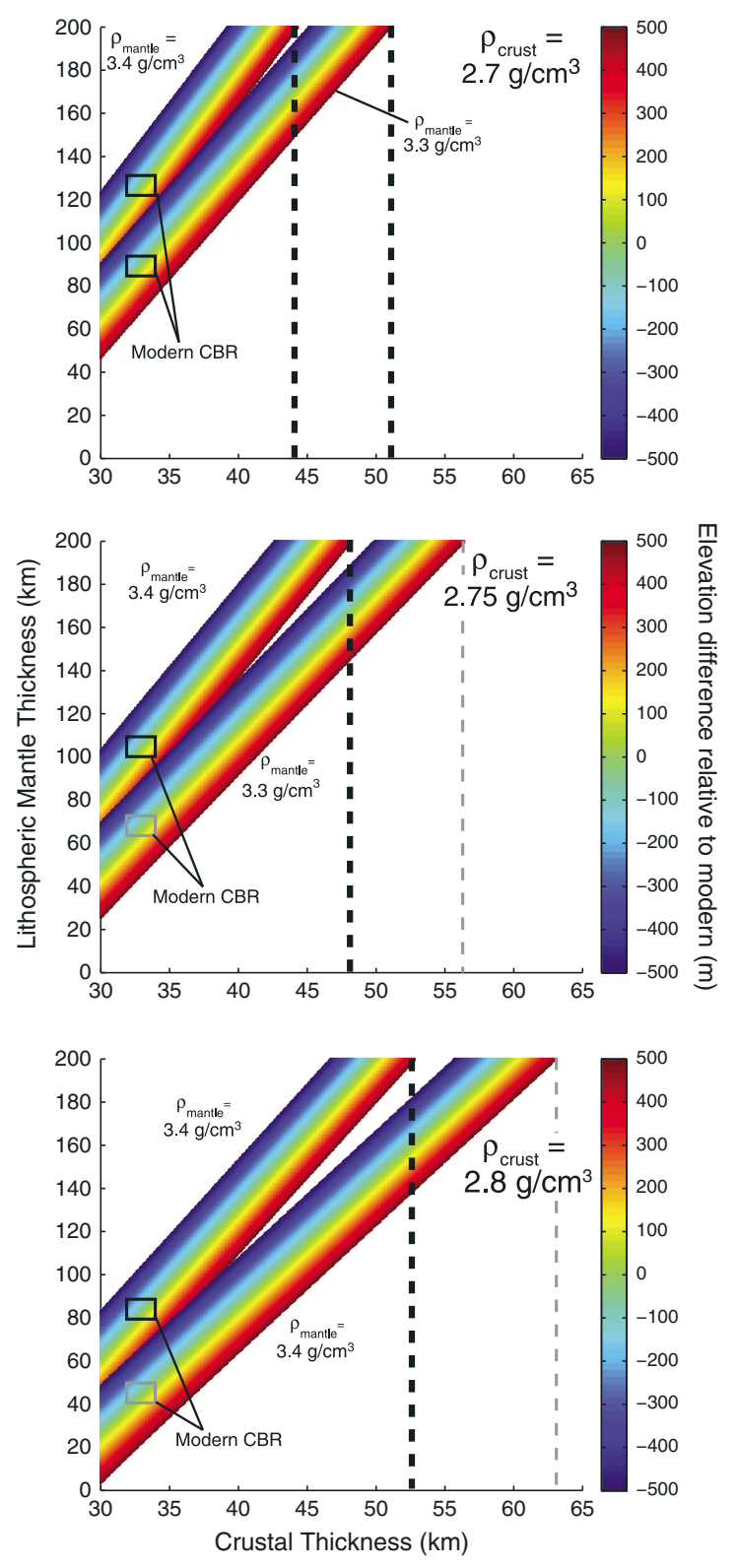

Figure 9. Isostatic calculations of central Basin and Range (CBR) (paleo)elevations following the method of Lachenbruch and Morgan [1990] and Schulte-Pelkum et al. [2011]. Elevation calculations are presented for $\rho_{\text {crust }}=$ $2.7,2.75$, and $2.8 \mathrm{~g} / \mathrm{cm}^{3}$ and $\rho_{\text {mantle }}$ (mantle lithosphere) $=$ 3.3 and $3.4 \mathrm{~g} / \mathrm{cm}^{3}$. Color bar shows calculated elevation values relative to modern mean CBR elevations of $1 \mathrm{~km}$ (i.e., if combination of crust and mantle lithosphere densities and thicknesses yields a $1 \mathrm{~km}$ calculated elevation [0 $\mathrm{m}$ elevation difference], it is colored light green); the -500 to 500 $\mathrm{m}$ range equates to (paleo)elevations of 500-1500 m, which is the constrained paleoelevation range for the middle Miocene Death Valley area based on carbonate $\Delta_{47}$ analysis of this study. Dashed lines show maximum crustal thicknesses permitted for $\sim 1500 \mathrm{~m}$ paleoelevations (heavy, black lines and boxes for density combinations that produce total lithospheric thickness comparable to modern CBR estimates [>100 km for 30-34 km thick crust; Schulte-Pelkum et al., 2011]; gray lines and boxes for thicknesses that do not match modern observations).
2008; Hren et al., 2010] suggest that the Sheep Pass basin was located at low-to-moderate paleoelevations on the order of $2 \mathrm{~km}$ or less. Such moderate paleoelevations in the protoBasin and Range are consistent with models proposing that peak regional elevations in the proto-NBR were attained immediately prior to or concomitant with the onset of widespread regional extension during late Eocene-Oligocene time (e.g., SWEEP) [Chamberlain et al., 2012]. In such a model, Basin and Range extension likely initiates as a result of a combination of forces: (1) thermal weakening of the Cordilleran interior lithosphere resulting from removal of the Farallon slab and replacement by hot asthenosphere [e.g., Humphreys, 1995] and (2) increase in gravitational potential energy and associated buoyancy forces due to $1-3 \mathrm{~km}$ of surface uplift. However, modest paleoelevations $(\leq 2 \mathrm{~km})$ in the Sheep Pass basin cannot preclude the existence of a high-elevation $(>3 \mathrm{~km})$ Nevadaplano in the early Paleogene Cordilleran interior. In this scenario, the Sheep Pass basin may have been an area of local, high-relief $(\geq 1 \mathrm{~km})$ [Druschke et al., 2009a, 2009b] in an otherwise high-elevation, plateaulike portion of the Cordilleran interior (Figure 10). Such high regional paleoelevations would be consistent with models that invoke internal buoyancy forces associated with excess gravitational potential energy of a preextension, orogenic highland as the primary driving forces for middle Cenozoic extension of the northern Basin and Range [e.g., Jones et al., 1998; Dilek and Moores, 1999; Sonder and Jones, 1999].

[54] In contrast, the low-to-moderate regional paleoelevations $(\leq 1.5 \mathrm{~km})$ in the middle Miocene Death Valley area indicate that internal buoyancy forces were not the primary drivers for Neogene central Basin and Range (CBR) extension. Instead, external boundary forces, both at the Pacific-North American plate boundary and in the neighboring southern and northern Basin and Range subprovinces, likely initiated CBR extension during the middle Miocene [e.g., Sonder and Jones, 1999]. The distinct paleoelevation histories of the northern and central Basin and Range indicate that a high-elevation $(>2 \mathrm{~km})$ Nevadaplano did not extend southward to the latitude of the central Basin and Range and southern Sierra Nevada $\left(35^{\circ} \mathrm{N}-37^{\circ} \mathrm{N}\right.$; Figure 10$)$ as has been previously proposed [e.g., Ernst, 2010; Henry et al., 2012]. This result is consistent with interpretations of detrital zircon data from $\mathrm{Pa}$ leocene-Eocene basins in the southern Sierra Nevada region [Lechler and Niemi, 2011b], which propose that (1) Paleogene drainages sourced in the high-elevation continental interior that crossed the Sierra Nevada [Cassel et al., 2009b, 2012; Henry et al., 2012] were restricted to the central and northern Sierra Nevada (north of $\sim 37^{\circ} \mathrm{N}$ ); and (2) the Paleogene southern Sierra Nevada was a moderate-elevation (1-2 km) local topographic high surrounded to the east, west, and south by low-elevation $(\leq 1 \mathrm{~km})$ paleodrainages and depocenters (Figure 10). However, we cannot rule out continuation of the Nevadaplano highland through the eastern CBR during Miocene time (e.g., Lake Mead area), although published carbonate $\Delta_{47}$ records suggest modest middle Miocene paleoelevations of $\sim 1.5-2 \mathrm{~km}$ [Huntington et al., 2010] in the neighboring Colorado Plateau region as well.

[55] Isostatic calculations constrained by modern and middle Miocene CBR elevations and lithospheric structure indicate that synextensional crustal thinning and surface elevation change were significantly less than would be predicted if uniform thinning of Basin and Range crust had 


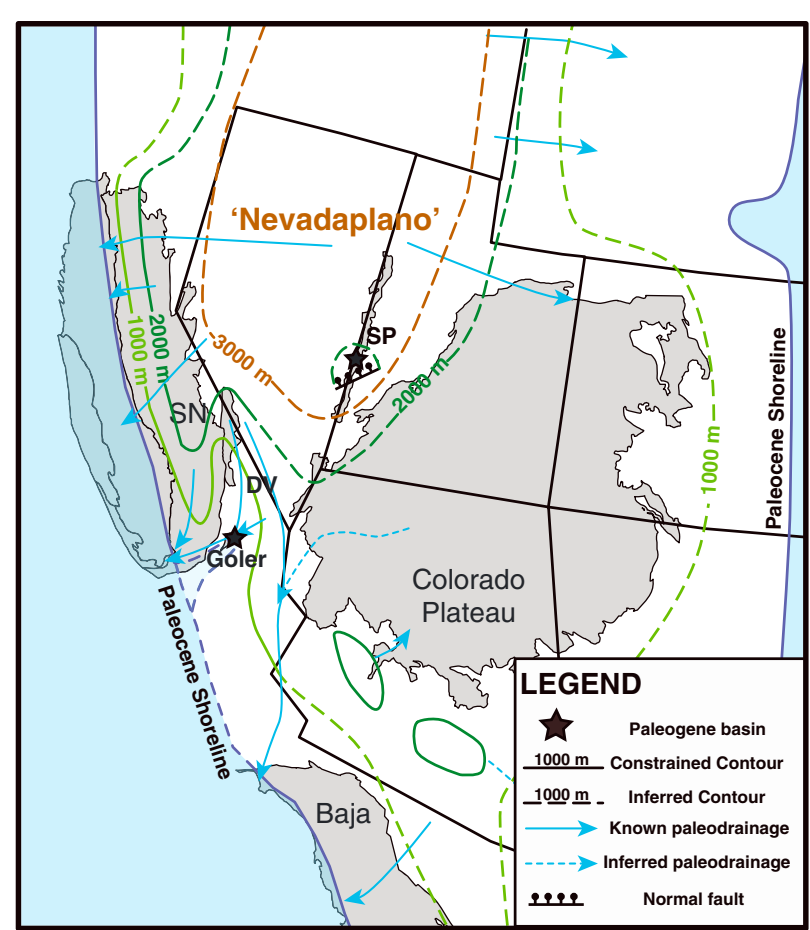

Figure 10. Early Cenozoic paleotopography and paleogeography of the western U.S. Cordillera with retrodeformed state boundaries. Locations of reference physiographic provinces (gray polygons) from McQuarrie and Wernicke [2005]. Paleotopographic contours and paleodrainages for the southern Sierra Nevada-Death Valley domain and "Nevadaplano" region are based on the results of this and published studies [Gregory-Wodzicki, 1997; Wolfe et al., 1998; Cassel et al., 2009a; Lechler and Niemi, 2011b]. Remaining contours and paleodrainages compiled from various sources (Sierra Nevada: Mulch et al. [2006]; Cassel et al. [2009b]; Hren et al. [2010]; Cecil et al. [2010]; Henry et al. [2012]; southern Basin and Range: Abbott and Smith [1989]; Howard [2000]; Wernicke [2011]; Sevier orogen: Henry [2008]; Fan and Dettman [2009]). SN = Sierra Nevada, $\mathrm{SP}=$ Sheep Pass, DV $=$ Death Valley.

occurred during $>100 \%$ crustal extension. The lack of significant synextensional crustal thinning is consistent with simple shear models of Basin and Range extension in which major thinning of the lithosphere occurs without significant crustal thinning [e.g., Wernicke, 1985], but the minor $(<500 \mathrm{~m})$ elevation change during extension is less well understood. Dynamic uplift from the asthenospheric mantle, crustal flow into the extending region [e.g., Wernicke et al., 1996; Snow and Wernicke, 2000], and/or magmatic additions to the crust during extension [e.g., Lachenbruch and Morgan, 1990; Hawkesworth et al., 1995] are all potential mechanisms to account for the observed, small synextensional elevation change. However, the presence of a thick $(\sim 125 \mathrm{~km})$ and dense mantle lithosphere below the Death Valley region rules out mantle buoyancy sources for modern central Basin and Range elevations [Schulte-Pelkum et al., 2011]. Crustal flow mass redistribution is also an unlikely compensation mechanism in the CBR as such flow requires hot and thick crustal flow channels that commonly only occur within substantially thickened crust [e.g., Wernicke et al., 2008], which the paleoelevation estimates presented here would appear to rule out. As a result, the most viable mechanism to explain why modern regional crustal thicknesses are relatively thick, and synextensional elevation change was relatively minor, is that new crustal material was added via magmatism to the CBR crust during Neogene extension. Assuming a preextension CBR crustal thickness of $\sim 50 \mathrm{~km}$ and $\sim 100 \%$ crustal extension and thinning requires the addition of $\sim 5-9 \mathrm{~km}$ of crustal material to account for modern crustal thicknesses of $\sim 30-34 \mathrm{~km}$. Such magmatic addition magnitudes are in broad agreement with estimates for the eastern Great Basin and southern Basin and Range ( $\sim 5 \mathrm{~km})$ [Gans, 1987; Hawkesworth et al., 1995], suggesting that addition of magmatic material to the CBR crust during extension may have been a primary influence on the synextensional topographic evolution of the CBR.

\section{Conclusions}

[56] This study highlights the utility and complications of carbonate clumped isotope thermometry for paleoelevation studies, particularly when known sea level proxies can be studied. Via calculation of meteoric water isotopic $\left(\delta^{18} \mathrm{O}\right)$ values, independent measures of carbonate growth temperatures can constrain postdepositional isotopic modification influences to proxy isotopic records (e.g., evaporation), which is often not possible in standard stable isotope paleoaltimetry approaches. Calculated $\Delta_{47}$ temperatures also allow for direct comparison with independent measures of paleotemperatures (e.g., paleobotanical), particularly when recently published $\Delta_{47}$-MAAT transfer functions [Hren and Sheldon, 2012] are applied, thus yielding more robust paleoelevation estimates.

[57] High $\Delta_{47}$ temperatures $\left(>47^{\circ} \mathrm{C}\right)$ measured for micrite collected from the near-sea level Paleocene Goler Formation of the southern Sierra Nevada region suggest that at least partial low-temperature diagenetic resetting of the Goler micrite has occurred, which precludes the use of this micrite as a paleo-sea level temperature datum. However, petrographic and cathodoluminescence analyses indicate that the micrite has not undergone observable recrystallization. This apparent contradiction highlights the importance of better constraining the $\Delta_{47}$-temperature calibration, particularly in the $40^{\circ} \mathrm{C}-70^{\circ} \mathrm{C}$ temperature range, and points to the need to develop diagnostic tests for identifying low-temperature diagenesis. Furthermore, identification of diagenetic influence based solely on measured $\Delta_{47}$ temperatures $>33^{\circ} \mathrm{C}$ [Huntington et al., 2010] is potentially problematic as many carbonate proxies form when seasonal surface temperatures are at a maximum such that recorded $\Delta_{47}$ temperatures may significantly exceed MAAT. In particular, paleosol carbonate $\Delta_{47}$ temperatures can exceed MAAT by $\sim 10^{\circ} \mathrm{C}-15^{\circ} \mathrm{C}$ [Quade et al., 2011, 2012]. Accordingly, during past greenhouse conditions (e.g., early Eocene Climatic Optimum and Paleocene-Eocene Thermal Maximum) when middle-latitude SSTs reached $33^{\circ} \mathrm{C}-34^{\circ} \mathrm{C}$ [Zachos et al., 2006; Sluijs et al., 2007], it is not unreasonable to expect to record $\Delta_{47}$ temperatures on the order of $40^{\circ} \mathrm{C}-50^{\circ} \mathrm{C}$, values which are difficult to discern from low-temperature diagenesis, as exemplified by the Goler Formation micrite of this study. Future work will utilize the abundant paleotemperature proxies (lignite, fossil wood, goethite, and paleosol carbonates) accessible in the Goler Formation to provide more robust paleotemperature estimates for the Paleocene Goler 
basin and elucidate the influence of diagenesis to Goler micrite $\Delta_{47}$ temperatures.

[58] As applied here, carbonate clumped isotope $\left(\Delta_{47}\right)$ thermometry study of lacustrine basins in east central Nevada of the northern Basin and Range and the Death Valley domain of the central Basin and Range provides new estimates of preextensional absolute paleoelevations in each region. Comparison of Late Cretaceous-Eocene MAAT estimates for the Cordilleran interior Sheep Pass basin $\left(\sim 16^{\circ} \mathrm{C}-20^{\circ} \mathrm{C}\right)$, derived from published lacustrine carbonate $\Delta_{47}$-MAAT transfer functions, with published MAAT estimates for the Eocene paleo-Pacific Coast at the latitude of the northern Sierra Nevada $\left(\sim 20^{\circ} \mathrm{C}-25^{\circ} \mathrm{C}\right)$ yields paleoelevation estimates for the Sheep Pass basin of $\leq 2 \mathrm{~km}$. These modest paleoelevation estimates tentatively support models calling for $1-3 \mathrm{~km}$ of surface uplift throughout the proto-northern Basin and Range during the late Eoceneearly Oligocene. However, it is important to note that modest early Paleogene paleoelevations in the Sheep Pass basin do not rule out the existence of a high-elevation, orogenic plateau ("Nevadaplano") in the western U.S. Cordilleran interior during early Paleogene time as deposition of the Sheep Pass Formation is known to have occurred in a local, high-relief ( $\geq 1 \mathrm{~km}$ ) basin setting that may have been contained within the high-elevation Nevadaplano.

[59] Carbonate clumped isotope thermometry study of middle Miocene basins in the Death Valley-southern Sierra Nevada region provides robust measures of preextensional absolute paleoelevations in the central Basin and Range. Similar lacustrine carbonate growth temperatures $\left(\sim 25^{\circ} \mathrm{C}-35^{\circ} \mathrm{C}\right)$ and $\Delta_{47}$-derived MAAT $\left(\sim 17^{\circ} \mathrm{C}-24^{\circ} \mathrm{C}\right)$ for middle Miocene basins in both the Death Valley area and the near-sea level southern Sierra Nevada Bena basin suggest that preextensional paleoelevations in the western central Basin and Range were $\leq 1.5 \mathrm{~km}$, indicating that synextensional mean elevation change was minor $(<500 \mathrm{~m})$ despite regional extension amounts of $>100 \%$.

[60] The distinct preextensional paleoelevation histories for the central and northern Basin and Range likely reflect the unique tectonic and geodynamic histories of each region. The proto-northern Basin and Range was the locus of Sevier contraction and crustal thickening [e.g., DeCelles, 2004] and was subject to a southward sweep in magmatism and potentially significant surface uplift as a result of Eocene removal of the Farallon slab from below the region. Exact timing of when the proto-northern Basin and Range reached maximum preextensional elevations of $>3 \mathrm{~km}$ remains unresolved at present, but, in any case, buoyancy forces resulting from high regional topography acted as a primary driving force for the widespread middle Cenozoic extension that ultimately formed the northern Basin and Range subprovince [Sonder and Jones, 1999]. In contrast, the preservation of thick Precambrian lithosphere throughout much of the central Basin and Range [Schulte-Pelkum et al., 2011], in combination with regional Late Cretaceousearly Paleogene gravitational collapse associated with the disaggregation of the adjacent Mojave-southern Sierra Nevada crustal batholith as a result of Laramide flat slab subduction [e.g., Wood and Saleeby, 1997; Chapman et al., 2012], resulted in low $(\leq 1.5 \mathrm{~km})$ preextensional paleoelevations in the Death Valley and neighboring regions. These results indicate that modern topographic variability in the Basin and Range (e.g., $\sim 1 \mathrm{~km}$ "topographic step" at $\sim 37^{\circ} \mathrm{N}$ ) likely reflects regional preextensional tectonic histories and lithospheric structure heterogeneity and is not controlled by variable magnitudes of Cenozoic extension.

[61] Acknowledgments. Lora Wingate at the UM Stable Isotope Laboratory is thanked for assistance with stable and clumped isotopic analysis. Will DeFliese assisted with clumped analyses and was instrumental in constructing heated gas and equilibrated $\mathrm{CO}_{2}$ reference lines as well as calculating normalized $\Delta_{47}$ values and temperatures. Majie Fan and Kate Huntington are thanked for their reviews. This work was partially supported by a UM Turner Award (A.R.L.), a UM Turner Postdoctoral Fellowship (M.T.H.), and NSF grant EAR-1151247 (N.A.N.).

\section{References}

Abbott, P. L., and T. E. Smith (1989), Sonora, Mexico, source for the Eocene Poway Conglomerate of southern California, Geology, 17, 329-332, doi:10.1130/0091-7613(1989)017<0329:SMSFTE $>2.3 . C O ; 2$.

Ahdyar, A. (2011), Molecular organic geochemistry of the oil and source rock in Railroad Valley, eastern Great Basin, Nevada, United States, M. S. thesis, Univ. of Nevada, Las Vegas.

Albright, L. B., D. L. Lofgren, and M. C. McKenna (2009), Magnetostratigraphy, mammalian biostratigraphy, and refined age assessment of the Goler Formation (Paleocene), California, in Papers on Geology, Vertebrate Paleontology, and Biostratigraphy in Honor of Michael O. Woodburne, vol. 65, edited by L. B. Albright, pp. 259-278, Flagstaff, Ariz. Bartow, J. A. (1981), Geologic map of the Rio Bravo Ranch Quadrangle, scale 1:24000, U.S. Geol. Surv., Reston, Va.

Bartow, J. A., and K. McDougall (1984), Tertiary stratigraphy of the southeastern San Joaquin Valley, California, U.S. Geol. Surv. Bull., $1529,1-41$.

Best, M. G., D. L. Barr, E. H. Christiansen, S. Gromme, A. L. Deino, and D. G. Tingey (2009), The Great Basin Altiplano during the middle Cenozoic ignimbrite flareup: Insights from volcanic rocks, Int. Geol. Rev., 51, 589-633, doi:10.1080/00206810902867690.

Bortz, L. C., and D. K. Murray (1979), Eagle Springs oil field, Nye County, Nevada, AAPG Bull., 62, 881.

Burchfiel, B. C. (1966), Reconnaissance geologic map of the Lathrop Wells 15-minute quadrangle Nye County, Nevada, scale 1:62500, U.S. Geol. Surv., Washington, D. C.

Cassel, E. J., A. Calvert, and S. A. Graham (2009a), Age, geochemical composition, and distribution of Oligocene ignimbrites in the northern Sierra Nevada, California: Implications for landscape morphology, elevation, and drainage divide geography of the Nevadaplano, Int. Geol. Rev., 51, 723-742, doi:10.1080/00206810902880370.

Cassel, E. J., S. A. Graham, and C. P. Chamberlain (2009b), Cenozoic tectonic and topographic evolution of the northern Sierra Nevada, California, through stable isotope paleoaltimetry in volcanic glass, Geology, 37, 547-550, doi:10.1130/G25572A.1.

Cassel, E. J., S. A. Graham, C.P. Chamberlain, and C. D. Henry (2012), Early Cenozoic topography, morphology, and tectonics of the northern Sierra Nevada and western Basin and Range, Geosphere, 8, 229-249, doi:10.1130/GES00671.1.

Cecil, M. R., M. N. Ducea, P. Reiners, G. Gehrels, A. Mulch, C. Allen, and I. Campbell (2010), Provenance of Eocene river sediments from the central northern Sierra Nevada and implications for paleotopography, Tectonics, 29, TC6010, doi:10.1029/2010TC002717.

Chamberlain, C. P., H. T. Mix, A. Mulch, M. T. Hren, M. L. Kent-Corson, S. J. Davis, T. W. Horton, and S. A. Graham (2012), The Cenozoic climatic and topographic evolution of the western North American Cordillera, Am. J. Sci., 312(2), 213-262, doi:10.2475/02.2012.05.

Chapman, A. D., J. B. Saleeby, D. J. Wood, A. Piasecki, S. Kidder, M. N. Ducea, and K. A. Farley (2012), Late Cretaceous gravitational collapse of the southern Sierra Nevada batholith, California, Geosphere, 8, 314-341, doi:10.1130/GES00740.1.

Chase, C. G., K. M. Gregory-Wodzicki, J. T. Parrish, and P. DeCelles (1998), Topographic history of the western Cordillera of North America and controls on climate, in Tectonic boundary conditions for climate model simulations, edited by T. J. Crowley and K. Burke, pp. 73-99, Oxford Univ. Press, Oxford, U. K.

Colgan, J. P., and C. D. Henry (2009), Rapid middle Miocene collapse of the Sevier orogenic plateau in north central Nevada, Int. Geol. Rev., 51, 920-961, doi:10.1080/00206810903056731.

Coney, P. J., and T.A. Harms (1984), Cordilleran metamorphic core complexes: Cenozoic extensional relics of Mesozoic compression, Geology, 12, 550-554, doi:10.1130/0091-7613(1984)12<550:CMCCCE > 2.0.CO;2. 


\section{LECHLER ET AL.: $\Delta_{47}$ PALEOALTIMETRY OF BASIN AND RANGE}

Cox, B. F. (1982), Stratigraphy, sedimentology, and structure of the Goler Formation (Paleocene), El Paso Mountains, California: Implications for Paleogene tectonism on the Garlock Fault Zone, Ph.D. thesis, University of California, Riverside.

DeCelles, P. G. (2004), Late Jurassic to Eocene evolution of the Cordilleran thrust belt and foreland basin system, western U.S., Am. J. Sci., 304, 105-168, doi:10.2475/ajs.304.2.105.

DeCelles, P. G., and J. C. Coogan (2006), Regional structure and kinematic history of the Sevier fold-and-thrust belt, central Utah, Geol. Soc. Am. Bull., 118, 841-864, doi:10.1130/B25759.1.

Dennis, K. J., and D. P. Shrag (2010), Clumped isotope thermometry of carbonatites as an indicator of diagenetic alteration, Geochim. Cosmochim. Acta, 74(14), 4110-4122, http://dx.doi.org/10.1016/j.gca.2010.04.005.

Dennis, K. J., H. P. Affek, B. H. Passey, D. P. Shrag, and J. M. Eiler (2011), Defining an absolute reference frame for 'clumped' isotope studies of $\mathrm{CO}_{2}$, Geochim. Cosmochim. Acta, 75(22), 7117-7131, http://dx.doi.org/ 10.1016/j.gca.2011.09.025.

Dettman, D. L., and K. C. Lohmann (1995), Microsampling carbonates for stable isotope and minor element analysis - physical separation of samples on a 20 micrometer scale, J. Sediment. Res., Sect. A, 65(3), 566-569, doi:10.1306/D426813F-2B26-11D7-8648000102C1865D

Dickinson, W. R. (2006), Geotectonic evolution of the Great Basin, Geosphere, 2, 353-368, doi:10.1130/GES00054.1.

Dilek, Y., and E. M. Moores (1999), A Tibetan model for the early Tertiary western United States, J. Geol. Soc. London, 156, 929-941, doi:10.1144/ gsjgs.156.5.0929.

Druschke, P., A. D. Hanson, M. L. Wells, T. Rasbury, D. F. Stockli, and G. Gehrels (2009a), Synconvergent surface-breaking normal faults of Late Cretaceous age within the Sevier hinterland, east-central Nevada, Geology, 37, 447-450, doi:10.1130/G25546A.1.

Druschke, P., A. D. Hanson, and M. Wells (2009b), Structural, stratigraphic and geochronologic evidence for extension predating Palaeogene volcanism in the Sevier hinterland, east-central Nevada, Int. Geol. Rev., 51, 743-775, doi:10.1080/00206810902917941

Eiler, J. M. (2011), Paleoclimate reconstruction using carbonate clumped isotope thermometry, Quat. Sci. Rev., 30(25-26), 3575-3588, http://dx. doi.org/10.1016/j.quascirev.2011.09.001.

Eiler, J. M., and E. Schauble (2004), ${ }^{18} \mathrm{O}^{13} \mathrm{C}^{16} \mathrm{O}$ in Earth's atmosphere, Geochim. Cosmochim. Acta, 68, 4767-4777, doi:10.1016/j.gca.2004.05.035.

England, P., and G. Houseman (1989), Extension during continental convergence, with application to the Tibetan Plateau, J. Geophys. Res. 94(B12), 17561-17579, doi:10.1029/JB094iB12p17561.

Ernst, W. G. (2010), Young convergent margins, climate, and crustal thickness - A Late Cretaceous-Paleogene Nevadaplano in the American Southwest?, Lithosphere, 2, 67-75, doi:10.1130/L84.1.

Fan, M. J., and D. L. Dettman (2009), Late Paleocene high Laramide ranges in northeast Wyoming: Oxygen isotope study of ancient river water, Earth Planet. Sci. Lett., 286(1-2), 110-121, http://dx.doi.org/10.1016/j. eps1.2009.06.024.

Ferry, J. M., B. H. Passey, C. Vasconcelos, and J. M. Eiler (2011), Formation of dolomite at $40-80^{\circ} \mathrm{C}$ in the Latemar carbonate buildup, Dolomites, Italy, from clumped isotope thermometry, Geology, 39(6), 571-574, doi:10.1130/G31845.1.

Fouch, T. D. (1979), Character and paleogeographic distribution of Upper Cretaceous(?) and Paleogene nonmarine sedimentary rocks in east-central Nevada, in Cenozoic Paleogeography of the Western United States: Pacific Coast Paleogeographic Symposium 3, edited by J. M. Armentrout et al., pp. 97-111, Pacific Section, SEPM, Los Angeles, CA

Fricke, H. C., and S. L. Wing (2004), Oxygen isotope and paleobotanical estimates of temperature and $\delta^{18} \mathrm{O}$-latitude gradients over North America during the early Eocene, Am. J. Sci., 304(7), 612-635, doi:10.2475/ ajs.304.7.612.

Fridrich, C. J., and R. A. Thompson (2011), Cenozoic tectonic reorganizations of the Death Valley region, southeast California and southwest Nevada, U.S Geol. Surv. Prof. Pap. 1783, 36 pp.

Fridrich, C. J., R. A. Thompson, J. L. Slate, M. E. Berry, and M. N. Machette (2008), Preliminary geologic map of the southern Funeral Mountains and adjacent ground-water discharge sites, Inyo County, California, and Nye County, Nevada, scale 1:50000, U.S. Geol. Surv. Open File Rep. $2008-1366$

Friedman, I., J. M. Harris, G. I. Smith, and C. A. Johnson (2002), Stable isotope composition of waters in the Great Basin, United States: 1. Air-mass trajectories, J. Geophys. Res., 107(D19), 4400, doi:10.1029/ 2001JD000565.

Gans, P. B. (1987), An open-system, two-layer crustal stretching model for the Eastern Great Basin, Tectonics, 6(1), 1-12, doi:10.1029/TC006i001p00001.

Gébelin, A., A. Mulch, C. Teyssier, C. P. Chamberlain, and M. Heizler (2012), Coupled basin-detachment systems as paleoaltimetry archives of the western North America Cordillera, Earth Planet. Sci. Lett., 335-336, 36-47, doi:10.1016/j.eps1.2012.04.029.
Ghosh, P., J. Adkins, H. Affek, B. Balta, W. Guo, E. Schauble, D. Schrag, and J. Eiler (2006a), ${ }^{13} \mathrm{C}-{ }^{18} \mathrm{O}$ bonds in carbonate minerals: A new kind of paleothermometer, Geochim. Cosmochim. Acta, 70, 1439-1456, doi:10.1016/j.gca.2005.11.014

Ghosh, P., C. N. Garzione, and J. M. Eiler (2006b), Rapid uplift of the Altiplano revealed through ${ }^{13} \mathrm{C}-{ }^{18} \mathrm{O}$ bonds in paleosol carbonates, Science 311(5760), 511-515, doi:10.1126/science.1119365.

Good, S. C. (1987), Mollusc-based interpretations of lacustrine paleoenvironments of the Sheep Pass Formation (Latest Cretaceous to Eocene) of east central Nevada, Palaios, 2(5), 476-478

Gregory-Wodzicki, K. M. (1997), The Late Eocene House Range flora, Sevier Desert, Utah: Paleoclimate and paleoelevation, Palaios, 12(6), 552-567.

Guo, W., J. L. Mosenfelder, W. A. Goddard III, and J. M. Eiler (2009), Isotopic fractionations associated with phosphoric acid digestion of carbonate minerals: Insights from first-principles theoretical modeling of clumped isotope measurements, Geochim. Cosmochim. Acta, 73(24), 7203-7225, http://dx.doi.org/10.1016/j.gca.2009.05.071.

Hawkesworth, C., S. Turner, K. Gallagher, A. Hunter, T. Bradshaw, and N. Rogers (1995), Calc-alkaline magmatism, lithospheric thinning and extension in the Basin and Range, J. Geophys. Res., 100(B6), 10271-10286, 10.1029/94JB02508.

Henry, C. D. (2008), Ash-flow tuffs and paleovalleys in northeastern Nevada: Implications for Eocene paleogeography and extension in the Sevier hinterland, northern Great Basin, Geosphere, 4, 1-35, doi:10.1130/GES00122.1.

Henry, C. D., and J. E. Faulds (2010), Ash-flow tuffs in the Nine Hill, Nevada, paleovalley and implications for tectonism and volcanism of the western Great Basin, USA, Geosphere, 6, 339-369, doi:10.1130/GES00548.1.

Henry, C. D., N. H. Hinz, J. E. Faulds, J. P. Colgan, D. A. John, E. R. Brooks, E. J. Cassel, L. J. Garside, D. A. Davis, and S. B. Castor (2012), Eocene-Early Miocene paleotopography of the Sierra NevadaGreat Basin-Nevadaplano based on widespread ash-flow tuffs and paleovalleys, Geosphere, 8, 1-27, doi:10.1130/GES00727.1.

Herbert, T. D., J. D. Schuffert, D. Anderson, L. Heusser, M. Lyle, A. Mix, A. C. Ravelo, L. D. Stott, and J. C. Herguera (2001), Collapse of the California Current during glacial maxima linked to climate change on land, Science, 293(5527), 71-76, doi:10.1126/science.1059209.

Hodges, K. V., and J. D. Walker (1992), Extension in the Cretaceous Sevier orogeny, North American Cordillera, Geol. Soc. Am. Bull., 104(5), 560-569, doi:10.1130/0016-7606(1992)104<0560:EITCSO > 2.3.CO;2.

Horton, T. W., and C. Chamberlain (2006), Stable isotopic evidence for Neogene surface downdrop in the Central Basin and Range Province, Geol. Soc. Am. Bull., 118, 475-490, doi:10.1130/B25808.

Horton, T. W., D. J. Sjostrom, M. J. Abruzzese, M. A. Poage, J. R. Waldbauer, M. Hren, J. L. Wooden, and C. P. Chamberlain (2004), Spatial and temporal variation of Cenozoic surface elevation in the Great Basin and Sierra Nevada, Am. J. Sci., 304, 862-888, doi:10.2475/ajs.304.10.862.

Howard, J. L. (2000), Provenance of quartzite clasts in the Eocene-Oligocene Sespe Formation: Paleogeographic implications for southern California and the ancestral Colorado River, Geol. Soc. Am. Bull., 112, 1635-1649, doi:10.1130/0016-7606(2000)112<1635:POQCIT>2.0.CO;2.

Hren, M. T., B. Bookhagen, P. M. Blisniuk, A. L. Booth, and C. P. Chamberlain (2009), $\delta^{18} \mathrm{O}$ and $\delta \mathrm{D}$ of streamwaters across the Himalaya and Tibetan Plateau: Implications for moisture sources and paleoelevation reconstructions, Earth Planet. Sci. Lett., 288(1-2), 20-32, http://dx.doi.org/10.1016/ j.eps1.2009.08.041.

Hren, M. T., M. Pagani, D. M. Erwin, and M. Brandon (2010), Biomarker reconstruction of the early Eocene paleotopography and paleoclimate of the northern Sierra Nevada, Geology, 38, 7-10, doi:10.1130/G30215.1.

Hren, M. T., and N. D. Sheldon (2012), Temporal variations in lake water temperature: Paleoenvironmental implications of lake carbonate $\delta^{18} \mathrm{O}$ and temperature records, Earth Planet. Sci. Lett., doi:10.1016/ j.eps1.2012.05.019.

Humphreys, E. D. (1995), Post-Laramide removal of the Farallon slab, western United States, Geology, 23(11), 987-990, doi:10.1130/00917613(1995)023<0987:PLROTF $>2.3 . \mathrm{CO} ; 2$.

Huntington, K. W., et al. (2009), Methods and limitations of "clumped" $\mathrm{CO}_{2}$ isotope $\left(\Delta_{47}\right)$ analysis by gas-source isotope-ratio mass spectrometry, J. Mass Spectrom., 44, 1318-1329, doi:10.1002/jms.1614.

Huntington, K. W., B. P. Wernicke, and J. M. Eiler (2010), Influence of climate change and uplift on Colorado Plateau paleotemperatures from carbonate clumped isotope thermometry, Tectonics, 29, TC3005, doi:10.1029/2009TC002449.

Ingraham, N. L., and B. E. Taylor (1991), Light stable isotope systematics of large-scale hydrologic regimes in California and Nevada, Water Resour. Res., 27(1), 77-90, doi:10.1029/90WR01708.

Jones, C. H., B. P. Wernicke, G. L. Farmer, J. D. Walker, D. S. Coleman, L. W. Mckenna, and F. V. Perry (1992), Variations across and along a major continental rift: An interdisciplinary study of the Basin and Range Province, western USA, Tectonophysics, 213(1-2), 57-96, http://dx.doi. org/10.1016/0040-1951(92)90252-2. 


\section{LECHLER ET AL.: $\Delta_{47}$ PALEOALTIMETRY OF BASIN AND RANGE}

Jones, C. H., L. J. Sonder, and J. R. Unruh (1998), Lithospheric gravitational potential energy and past orogenesis: Implications for conditions of initial basin and range and Laramide deformation, Geology, 26(7), 639-642, doi:10.1130/0091-7613(1998)026<0639:LGPEAP > 2.3.CO;2.

Kim, S. T. and J. R. O’Neil (1997), Equilibrium and nonequilibrium oxygen isotope effects in synthetic carbonates, Geochim. Cosmochim. Acta, 61(16), 3461-3475, http://dx.doi.org/10.1016/S0016-7037(97)00169-5.

Koukouzas, N. (2007), Mineralogy and geochemistry of diatomite associated with lignite seams in the Komnina Lignite Basin, Ptolemais, Northern Greece, Int. J. Coal Geol., 71, 276-286, doi:10.1016/j.coal.2006.09.002.

Lachenbruch, A. H., and P. Morgan (1990), Continental extension, magmatism and elevation; formal relations and rules of thumb, Tectonophysics, 174(1-2), 39-62, doi:10.1016/0040-1951(90)90383-J.

LaRiviere, J. P., A. C. Ravelo, A. Crimmins, P. S. Dekens, H. L. Ford, M. Lyle, and M. W. Wara (2012), Late Miocene decoupling of oceanic warmth and atmospheric carbon dioxide forcing, Nature, 486, 97-100, doi:10.1038/nature11200.

Lechler, A. R., and N. A. Niemi (2011a), Controls on the spatial variability of modern meteoric $\delta^{18} \mathrm{O}$ : Empirical constraints from the western U.S. and east Asia and implications for stable isotope studies, Am. J. Sci., 311, 664-700, doi:10.2475/08.2011.02.

Lechler, A. R., and N. A. Niemi (2011b), Sedimentologic and isotopic constraints on the Paleogene paleogeography and paleotopography of the southern Sierra Nevada, California, Geology, 39, 379-382, doi:10.1130/G31535.1.

Lechler, A. R., and N. A. Niemi (2012), The influence of snow sublimation on the isotopic composition of spring and surface waters in the southwestern United States: Implications for stable isotope-based paleoaltimetry and hydrologic studies, Geol. Soc. Am. Bull., 124(3-4), 318-334, doi:10.1130/ B30476.1.

Lechler, A. R., and J. Galewsky (2013), Refining paleoaltimetry reconstructions of the Sierra Nevada, California using air parcel trajectories, Geology, 41, 259-262, doi:10.1130/G33553.1.

Lofgren, D. L., J. G. Honey, M. C. McKenna, R. L. Zondervan, and E. E. Smith (2008), Paleocene primates from the Goler Formation of the Mojave Desert in California, in Geology and Vertebrate Paleontology of Western and Southern North America, Contributions in Honor of David P. Whistler, edited by X. Wang and L. G. Barnes, pp. 11-28, Los Angeles, CA.

Loomis, D. P., and D. W. Burbank (1988), The stratigraphic evolution of the El Paso basin, southern California: Implications for the Miocene development of the Garlock fault and uplift of the Sierra Nevada, Geol. Soc. Am. Bull., 100(1), 12-28, doi:10.1130/0016-7606(1988) $100<0012$ :TSEOTE $>2.3 . \mathrm{CO} ; 2$.

McQuarrie, N., and B. P. Wernicke (2005), An animated tectonic reconstruction of southwestern North America since $36 \mathrm{Ma}$, Geosphere, 1, 147-172, doi:10.1130/GES00016.1.

Meyer, H. W. (2007), A review of paleotemperature-lapse rate methods for estimating paleoelevation from fossil floras, Rev. Mineral. Geochem. 66, 155-171, doi:10.2138/rmg.2007.66.6.

Mix, H. T., A. Mulch, M. L. Kent-Corson, and C. P. Chamberlain (2011), Cenozoic migration of topography in the North American Cordillera, Geology, 39, 87-90, doi:10.1130/G31450.1.

Molnar, P. (2010), Deuterium and oxygen isotopes, paleoelevations of the Sierra Nevada, and Cenozoic climate, Geol. Soc. Am. Bull., 122 , 1106-1115, doi:10.1130/B30001.1.

Mulch, A., S. A. Graham, and C. P. Chamberlain (2006), Hydrogen isotopes in Eocene river gravels and paleoelevation of the Sierra Nevada, Science, 313, 87-89, doi:10.1126/science.1125986.

Niemi, N. A. (2013), Detrital zircon age distributions as a discriminator of tectonic versus fluvial transport; an example from the Death Valley extended terrane, Geosphere, 9(1), 126-137, doi:10.1130/GES00820.1.

Niemi, N. A., B. P. Wernicke, R. J. Brady, J. B. Saleeby, and G. C. Dunne (2001), Distribution and provenance of the middle Miocene Eagle Mountain Formation, and implications for regional kinematic analysis of the Basin and Range Province, Geol. Soc. Am. Bull., 113, 419-442, doi:10.1130/00167606(2001)113<0419:DAPOTM > 2.0.CO;2.

Oskin, M., J. Stock, and A. Martín-Barajas (2001), Rapid localization of Pacific-North America plate motion in the Gulf of California, Geology, 29(5), 459-462, doi:10.1130/0091-7613(2001)0290459: RLOPNA 2.0.CO;2.

Peppe, D. J., D. L. Royer, P. Wilf, and E. A. Kowalski (2010), Quantification of large uncertainties in fossil leaf paleoaltimetry, Tectonics, 29, TC3015, doi:10.1029/2009TC002549.

Peters, N. A., K. W. Huntington, and G. D. Hoke (2012), Hot or not? Impact of seasonally variable soil carbonate formation on paleotemperature and O-isotope records from clumped isotope thermometry, Earth Planet. Sci. Lett., 361, 208-218, doi:10.1016/j.eps1.2012.10.024.

Poage, M. A., and C. P. Chamberlain (2001), Empirical relationships between elevation and the stable isotope composition of precipitation: Considerations for studies of paleoelevation change, Am. J. Sci., 301 , 1-15, doi:10.2475/ajs.301.1.1.
Poulsen, C. J., and M. L. Jeffery (2011), Climate change imprinting on stable isotopic compositions of high-elevation meteoric water cloaks past surface elevations of major orogens, Geology, 39(6), 595-598, doi:10.1130/G32052.1.

Quade, J., C. Garzione, and J. Eiler (2007), Paleoelevation reconstruction using pedogenic carbonates, Rev. Mineral. Geochem., 66, 53-87, doi:10.2138/rmg.2007.66.3.

Quade, J., D. O. Breecker, M. Daëron, and J. Eiler (2011), The paleoaltimetry of Tibet: An isotopic perspective, Am. J. Sci., 311(2), 77-115, doi:10.2475/02.2011.01.

Quade, J., J. Eiler, M. Daëron, and H. Achyuthan (2012), The clumped isotope geothermometer in soil and paleosol carbonate, Geochim. Cosmochim. Acta, 105, 92-107, doi:10.1016/j.gca.2012.11.031.

Renik, B., and N. Christie-Blick (2013), A new hypothesis for the amount and distribution of dextral displacement along the Fish Lake Valley-Northern Death Valley-Furnace Creek fault zone, California-Nevada, Tectonics, 32, doi:10.1029/2012TC003170.

Reynolds, M. W. (1969), Stratigraphy and structural geology of the Titus and Titanothere Canyons Area, Death Valley, California, Ph.D. thesis, Univ. of Calif., Berkeley.

Rowley, D. B., and C. N. Garzione (2007), Stable isotope-based paleoaltimetry, Annu. Rev. Earth Planet. Sci., 35, 463-508, doi:10.1146/ annurev.earth.35.031306.140155.

Schmidt, M, S. Xeflide, R. Botz, and S. Mann, 2005, Oxygen isotope fractionation during synthesis of $\mathrm{CaMg}$-carbonate and implications for sedimentary dolomite formation, Geochim. Cosmochim. Acta, 69 , 4665-4674, http://dx.doi.org/10.1016/j.gca.2005.06.025.

Schulte-Pelkum, V., G. Biasi, A. Sheehan, and C. Jones (2011), Differential motion between upper crust and lithospheric mantle in the Central Basin and Range, Nat. Geosci., 4, 619-623, doi:10.1038/ngeo1229.

Sluijs, A., H. Brinkhuis, S. Schouten, S. M. Bohaty, C. M. John, J. C. Zachos, G. Reichart, J. S. Sinninghe Damsté, E. M. Crouch, and G. R. Dickens (2007), Environmental precursors to rapid light carbon injection at the Paleocene/Eocene boundary, Nature, 450, 1218-1221, doi:10.1038/nature06400.

Snow, J. K., and D. R. Lux (1999), Tectono-sequence stratigraphy of Tertiary rocks in the Cottonwood Mountains and northern Death Valley area, California and Nevada, in Cenozoic Basins of the Death Valley Region, Geol. Soc. Am. Spec. Pap., vol. 333, edited by L. A. Wright and B.W. Troxel, pp. 17-64, Boulder, CO, doi:10.1130/ 0-8137-2333-7.17.

Snow, J. K., and B. P. Wernicke (2000), Cenozoic tectonism in the Central Basin and Range: Magnitude, rate, and distribution of upper crustal strain Am. J. Sci., 300, 659-719, doi:10.2475/ajs.300.9.659.

Sonder, L. J., and C. H. Jones (1999), Western United States extension: How the West was widened, Annu. Rev. Earth Planet. Sci., 27, 417-462, doi:10.1146/annurev.earth.27.1.417.

Stewart, J. H. (1983), Extensional tectonics in the Death Valley area, California: Transport of the Panamint Range structural block $80 \mathrm{~km}$ northwestward, Geology, 11(3), 153-157, doi:10.1130/0091-7613(1983) $11<153:$ ETITDV $>2.0$. CO;2.

Torres, M., and R. Gaines (2011), Paleosol geochemistry of the late Paleocene Goler Formation of Southern California, Appl. Geochem., 26 , S135-S138, http://dx.doi.org/10.1016/j.apgeochem.2011.03.049.

Warthmann, R., Y. van Lith, C. Vasconcelos, J. A. McKenzie, and A. M. Karpoff (2000), Bacterially induced dolomite precipitation in anoxic culture experiments, Geology, 28(12), 1091-1094, doi:10.1130/ 0091-7613(2000)28<1091:BIDPIA > 2.0.CO;2

Wells, M. L., R. D. Dallmeyer, and R. W. Allmendinger (1990), Late Cretaceous extension in the hinterland of the Sevier thrust belt, northwestern Utah and southern Idaho, Geology, 18(10), 929-933, doi:10.1130/00917613(1990)018<0929:LCEITH > 2.3.CO;2.

Wells, M. L., and T. D. Hoisch (2008), The role of mantle delamination in widespread Late Cretaceous extension and magmatism in the Cordilleran orogen, western United States, Geol. Soc. Am. Bull., 120(5-6), 515-530, doi:10.1130/B26006.1.

Wernicke, B. (1985), Uniform-sense normal simple shear of continental lithosphere, Can. J. Earth Sci., 22(1), 108-125.

Wernicke, B. (1992), Cenozoic extensional tectonics of the U.S. Cordillera, in The Geology of North America, The Cordilleran Region, vol. G-3, edited by B. C. Burchfiel et al., pp. 553-581, GSA, Boulder, CO

Wernicke, B. P. (2011), The California River and its role in carving Grand Canyon, Geol. Soc. Am. Bull.,123, 1288-1316, doi:10.1130/B30274.1.

Wernicke, B., G. J. Axen, and J. K. Snow (1988), Basin and Range extensional tectonics at the latitude of the Las Vegas, Nevada, Geol. Soc. Am. Bull., 100(11), 1738-1757, doi:10.1130/0016-7606(1988) $100<1738$ :BARETA $>2.3 . \mathrm{CO} ; 2$.

Wernicke, B., et al. (1996), Origin of high mountains in the continents: The southern Sierra Nevada, Science, 271(5246), 190-193, doi:10.1126/ science.271.5246.190. 


\section{LECHLER ET AL.: $\Delta_{47}$ PALEOALTIMETRY OF BASIN AND RANGE}

Wernicke, B., J. L. Davis, N. A. Niemi, P. Luffi, and S. Bisnath (2008), Active megadetachment beneath the western United States, J. Geophys. Res., 113, B11409, doi:10.1029/2007JB005375.

Wolfe, J. A., C. E. Forest, and P. Molnar (1998), Paleobotanical evidence of Eocene and Oligocene paleoaltitudes in midlatitude western North America, Geol. Soc. Am. Bull., 110, 664-678, doi:10.1130/0016-7606 (1998) $110<0664$ :PEOEAO $>2.3 . C O ; 2$.

Wood, D., and J. Saleeby (1997), Late Cretaceous-Paleocene extensional collapse and disaggregation of the southernmost Sierra Nevada batholith, Int. Geol. Rev., 39, 973-1009, doi:10.1080/00206819709465314.

Yapp, C. J. (2008), ${ }^{18} \mathrm{O} /{ }^{16} \mathrm{O}$ and $\mathrm{D} / \mathrm{H}$ in goethite from a North American oxisol of the Early Eocene climatic optimum, Geochim. Cosmochim. Acta, 72, 5838-5851, doi:10.1016/j.gca.2008.09.002.
Yuan, H., and B. Romanowicz (2010), Lithospheric layering in the North American craton, Nature, 466, 1063-1068, doi:10.1038/nature09332.

Zachos, J. C., L. D. Stott, and K. C. Lohmann (1994), Evolution of early Cenozoic marine temperatures, Paleoceanography, 9(2), 353-387, doi:10.1029/93PA03266.

Zachos, J. C., M. Pagani, L. Sloan, E. Thomas, and K. Billups (2001), Trends, rhythms, and aberrations in global climate 65 Ma to Present, Science, 292, 686-693, doi:10.1126/science.1059412.

Zachos, J. C., S. Schouten, S. Bohaty, T. Quattlebaum, A. Sluijs, H. Brinkhuis, S. J. Gibbs, and T. J. Bralower (2006), Extreme warming of mid-latitude coastal ocean during the Paleocene-Eocene Therma Maximum: Inferences from $\mathrm{TEX}_{86}$ and isotope data, Geology, 34(9), 737-740, doi:10.1130/G22522.1 